Fordham Law School

FLASH: The Fordham Law Archive of Scholarship and History

Faculty Scholarship

2019

Toward an Interest Group Theory of Foreign Anti-Corruption Laws

Sean J. Griffith

Thomas H. Lee

Follow this and additional works at: https://ir.lawnet.fordham.edu/faculty_scholarship

Part of the Law Commons 


\title{
TOWARD AN INTEREST GROUP THEORY OF FOREIGN ANTI-CORRUPTION LAWS
}

\author{
Sean J. Griffith ${ }^{*}$ \\ Thomas H. Lee ${ }^{* *}$
}

Foreign anti-corruption laws-laws that prohibit businesses from paying bribes abroad - present a puzzle. Why would the government of one country care to prevent corruption in other countries, especially when such laws harm domestic businesses? Unregulated foreign competitors can continue to pay bribes and win contracts while domestic companies suffer. Yet foreign anti-corruption laws now span the globe.

We offer an interest-group account of the spread of foreign anti-corruption laws. Our account is bottom-up and focused on private interest groups, rather than top-down and focused on state institutions. We look at domestic political interests in the United States and abroad to explain both the enactment and the enforcement of foreign anti-corruption laws. Our principal focus is on each country's business lobby.

Our account explains observed patterns of enactment and enforcement of foreign anti-corruption laws and generates predictions concerning the efficacy of such laws based on the extraterritorial operations of multinational businesses. It also suggests a limitation on the spread of such laws into countries with few or no multinational corporations and, therefore, no realistic extraterritorial enforcement risk. The essential features of our account are: (1) after the Foreign Corrupt Practices Act ("FCPA") was enacted in 1977, U.S. businesses pressured the government to urge foreign governments to ratify multilateral anti-corruption treaties to bind foreign companies to similar anti-bribery restrictions; (2) these treaties required all signatory nations to enact foreign anti-corruption laws, which, in the United States, led to statutory amendments to the FCPA that enabled government agencies to apply the FCPA to foreign companies doing business in the United States; (3) as foreign companies operating in the United

* T. J. Maloney Chair and Professor of Law, Fordham Law School.

** Leitner Family Professor of International Law, Fordham Law School. Thanks to Afra Afsharipour, Rachel Brewster, Kevin Davis, Branislav Hock, Mike Koehler, Susan Rose-Ackerman, Nicola Sharpe, and Andy Spalding for their comments on earlier drafts. We are also grateful for comments and suggestions received after presentations at Brooklyn Law School, Fordham Law School, the University of Illinois College of Law, and at the 2015 American Society of International Law: Anti-Corruption Interest Group Workshop. Thanks to Amith Arcot, Alissa Black-Dorward, Steffanie Keim, and Vera Korzun for research assistance. The viewpoints and any errors expressed herein are the authors' alone. 
States were subject to FCPA enforcement, they supported or acquiesced in home-country enforcement of foreign anti-corruption laws to "level the playing field" against companies that did not face FCPA enforcement risk; and (4) going forward, the proliferation of enforcement of foreign anti-corruption laws among a dominant, hegemonic group of capital-exporting countries (a "k-group") may result in the global establishment of an anticorruption norm, with China potentially playing the role of counterhegemon.

\section{TABLE OF CONTENTS}

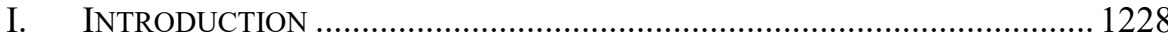

II. WHY Do WE CARE ABOUT ForEIGN CORRUPTION? ............................. 1234

III. A HISTORY OF THE ENACTMENT AND ENFORCEMENT OF FOREIGN

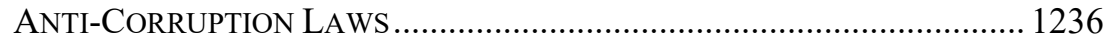

A. Foreign Policy and the Genesis of the FCPA............................ 1236

B. Business Interests Intervene ................................................... 1240

C. Multilateral Treaties and Ensuing Domestic Enactments............ 1244

D. A New Era of FCPA Enforcement ............................................. 1246

IV. CONTENDING THEORIES OF FOREIGN ANTI-CORRUPTION LAWS........... 1248

A. Rights-Based Accounts ............................................................ 1250

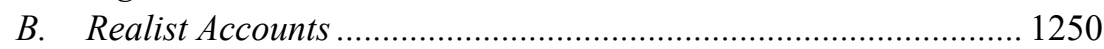

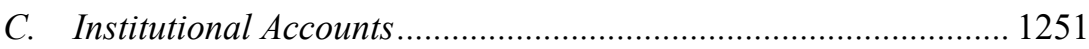

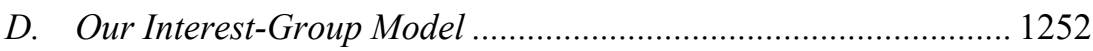

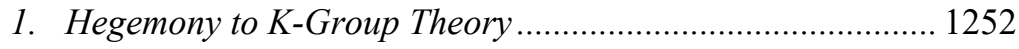

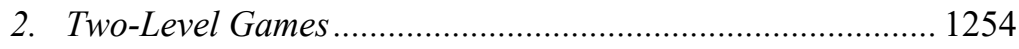

3. Putting it All Together ....................................................... 1255

V. CASE ANALYSIS OF OUR INTEREST GROUP THEORY.............................. 1257

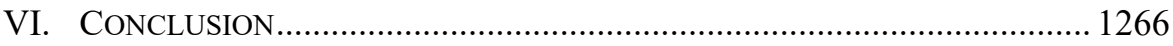

\section{INTRODUCTION}

Foreign anti-corruption laws-laws that prohibit businesses from paying bribes abroad - have proliferated around the globe. The United States took the lead in 1977 with the passage of the Foreign Corrupt Practices Act ("FCPA"), which criminalized what many then considered an ordinary cost of doing business abroad. ${ }^{1}$ Multilateral international treaties came two decades later, with the Organization for Economic Cooperation and Development (“OECD”) Anti-

1. Foreign Corrupt Practices Act of 1977, Pub. L. No. 95-213, 91 Stat. 1494 (1977), amended by the Omnibus Trade and Competitiveness Act of 1988, Pub. L. No. 100-418, tit. V, §§ 5001-03, 102 Stat. 1415 (1988), and the International Anti Bribery and Fair Competition Act of 1998, Pub. L. No. 105-366 (1998) (codified as amended at 15 U.S.C. $\S \S 78 \mathrm{~m}, 78 \mathrm{dd}-1,78 \mathrm{dd}-2,78 \mathrm{dd}-3$, $78 \mathrm{ff}$ (2018)). 
Bribery Convention in $1998,{ }^{2}$ followed by the United Nations Convention Against Corruption in 2003. Individual states' domestic laws against foreign corruption came next, in large part because the treaties obligated ratifying countries to enact domestic laws penalizing the payment of bribes to foreign officials. ${ }^{4}$ But enforcement, as we shall see, trailed enactment.

Foreign anti-corruption laws present a puzzle. Why would the government of one country care to prevent corruption in another? Laws against domestic corruption are longstanding and easy to justify. Corruption - the abuse of public power for private gain - distorts political decision-making and leads to the misallocation of government revenues, the degradation of civil services, and the disenfranchisement of the poor. Governments designed for the benefit of their people thus have a plain interest in preventing corruption at home. The reasons for promulgating laws to curtail foreign corruption, however, are much less apparent, especially considering that the principal means a government has at its disposal is to regulate the extraterritorial conduct of the domestic businesses paying the bribes to foreign officials. But without the ability to pay bribes abroad, domestic businesses may be at a competitive disadvantage vis-à-vis unregulated foreign businesses that will continue to supply bribes in bidding for the same international business contracts. The foreign competitor pays the bribe and wins the business while the domestic company suffers. Imposing pain on domestic business interests, given their lobbying power, is a dangerous political strategy for any government. So why would a government enact and then enforce foreign anti-corruption laws when the principal beneficiaries are the citizens of other countries? And, given the limited impact on the global supply of corruption of any unilateral state action, why even bother? Yet foreign anti-corruption laws exist and are increasingly being enforced across the globe.

This Article seeks to solve the puzzle by offering an interest-group account for the spread of foreign anti-corruption laws across the globe. It is important to distinguish at the start between enactment and enforcement of foreign anti-bribery laws, because the two trends do not go together. The FCPA, for example, was sparsely enforced for more than two decades after being enacted. ${ }^{5}$ The bevy of foreign anti-corruption laws passed by countries around the world in the wake

2. Organisation for Economic Cooperation and Development, Convention on Combating Bribery of Foreign Public Officials in International Business Transactions, Nov. 21, 1997, 37 I.L.M. 1.

3. United Nations Convention Against Corruption, opened for signature Dec. 9, 2003, 2349 U.N.T.S. 41 (entered into force Dec. 14, 2005).

4. Article 2 of the OECD Convention provided that "Each Party shall take such measures as may be necessary, in accordance with its legal principles, to establish the liability of legal persons for the bribery of a foreign public official." Organisation for Economic Co-operation and Development, Convention on Combating Bribery of Foreign Public Officials in International Business Transactions, supra note 2, at 7. Article 16 of the UNCAC mandated that ratifying states "adopt such legislative and other measures as may be necessary to establish as a criminal offence, when committed intentionally ... the promise, offering or giving to a foreign public official ... directly or indirectly, of an undue advantage" to "act or refrain from acting in the exercise of his or her official duties" related to international business. United Nations Convention Against Corruption, supra note 3 , at 17 .

5. See infra Section III.D. 
of the OECD Anti-Bribery Convention and the U.N. Convention Against Corruption have also been rarely enforced until very recently in a select few signatory countries. ${ }^{6}$ As of 2017, twenty-three of the forty-three states that ratified the OECD Convention had not conducted a single foreign-bribery prosecution. ${ }^{7}$ Moreover, despite the fanfare for the OECD and the U.N. Conventions, and the ratification of regional anti-corruption conventions in Africa, the Americas, and Europe, direct treaty-based enforcement has generally failed to materialize.

The pace of enforcement of foreign anti-corruption laws has accelerated dramatically in the twenty-first century. Most significantly, FCPA enforcement in the U.S. has ramped up not only against U.S.-based companies but also against multinational companies, mostly from capital-exporting economies. ${ }^{8}$ More recently, many of the countries whose companies have been the targets of FCPA enforcement - notably, the United Kingdom, Germany, France, and Brazilhave now not only enacted foreign anti-bribery laws, they have also begun to enforce them. ${ }^{9}$ Many other countries, meanwhile, continue not to enforce foreign anti-corruption laws, though most capital-exporting countries have enacted such laws. ${ }^{10}$

The explanation for trends in enactment and enforcement of foreign anticorruption laws outlined in this Article breaks from the existing literature. Much of the prior academic work focused exclusively on the FCPA and explains it either as a tool for the altruistic advancement of human rights ${ }^{11}$ or, alternatively, as a tool for prosecutorial rent extraction. ${ }^{12}$ Our account eschews both normatively tinged framings and looks instead to the political interest groups affected by the passage of foreign anti-bribery laws in various capital-exporting countries - not just the United States - to explain evolving trends. Our explanation also differs from institutionalist accounts that emphasize international organizations and domestic governance organs as the primary causal mechanisms for the spread of anti-corruption norms. ${ }^{13}$ Our analysis, by contrast, is bottom-up and

6. See infra Part V.

7. See OECD, Fighting the Crime of Foreign Bribery: The Anti-Bribery CONVENTION AND the OECD WORKING GROUP ON BRIBERY (2017), http://www.oecd.org/corruption/Fighting-the-crime-of-foreignbribery.pdf.

8. See infra Section III.D.

9. See infra Part V.

10. See infra Part V.

11. See, e.g., Andrew Brady Spalding, Corruption, Corporations, and the New Human Right, 91 WASH. U. L. REV. 1365 (2014); see also Matthew Murray \& Andrew Spalding, Freedom from Official Corruption as a Human Right, GOVERNANCE STUD. BROOKINGS (Brookings Inst., Washington D.C.), Jan. 2015, at 2.

12. See, e.g., Mike Koehler, Measuring the Impact of Non-Prosecution and Deferred Prosecution Agreements on Foreign Corrupt Practices Act Enforcement, 49 U.C. DAVIS L. REV. 497, 522 (2015) (arguing that "the use of NPAs and DPAs also allows the DOJ to feed its lucrative FCPA enforcement program"); see also Mike Koehler, The Uncomfortable Truths and Double Standards of Bribery Enforcement, 84 FORDHAM L. REV. 525, 541-44 (2015) (pointing to inconsistencies between the aspirational goals of ending bribery and enforcement patterns of the FCPA).

13. See, e.g., Rachel Brewster, Enforcing the FCPA: International Resonance and Domestic Strategy, 103 VA. L. REV. 1611, 1619 (2017) (arguing that the FCPA required "international resonance" through the OECD before it could be meaningfully enforced); see also Rachel Brewster \& Samuel W. Buell, The Market for Global 
focused on private interest groups, rather than top-down and focused on state institutions.

Our interest-group based theory posits that observed patterns of enactment and enforcement can be explained by looking to the incentives of each country's domestic business lobby. Consider first the United States. Immediately after the FCPA was passed in 1977, U.S. business interests favored lax enforcement, if not outright repeal. ${ }^{14}$ That was the status quo for over two decades. At the same time, a second-best preference of U.S. multinational corporations was to obtain a "level playing field" vis-à-vis foreign competitors not subject to the FCPA. ${ }^{15}$ This goal was eventually attained in the form of the 1998 OECD Convention and, just as critically, in resultant amendments to the FCPA empowering the U.S. Department of Justice ("DOJ") to enforce the statute vigorously against foreign companies with some connection to the U.S. ${ }^{16}$ Achieving robust enforcement against foreign competitors was a key component of getting U.S. business interests on board. ${ }^{17}$ But our story does not end there.

Now consider the incentives facing a foreign multinational corporation in the wake of the OECD Convention. The best case would be for its home jurisdiction not to enact any foreign anti-bribery law, but that option is foreclosed by the explicit provisions of the Convention. ${ }^{18}$ The second-best option is lax homestate enforcement after enactment, which was the outcome multi-national corporations in OECD countries with foreign-corruption laws did achieve for over a decade.

The incentives of foreign multi-nationals changed, however, after the U.S. Congress amended the FCPA in 1998 to permit enforcement against foreign companies based on minimum contacts with the United States - for example, by currency passed through a U.S. depository institution - and the DOJ and Securities and Exchange Commission ("SEC") demonstrated willingness to carry out aggressive enforcement against them. Those that bore U.S. enforcement risk now had a substantial incentive to stop paying bribes anywhere and to implement strong FCPA compliance programs. Such compliance measures put these foreign companies at a competitive disadvantage with respect to regional and domestic competitors who operated without significant U.S. enforcement risk and who therefore continued to pay bribes to win international business contracts. Consequently, foreign multinationals subject to FCPA enforcement developed a level playing field interest parallel to that of U.S. multinationals prior to enactment of the OECD. But for foreign companies, a level playing field entailed enactment and enforcement of foreign anti-bribery laws in home jurisdictions as against

Anticorruption Enforcement, 80 L. \& CONTEMP. PROBLEMS 193, 198-200 (explaining FCPA enforcement patterns by reference to the institutional incentives of enforcers).

14. See infra Section III.B.

15. See infra Section III.B.

16. See infra Section III.C.

17. See Brewster, supra note 13, at 1615 (arguing that "the FCPA could not be robustly enforced until federal prosecutors could adopt ... an enforcement strategy that allowed them to charge both American corporations and their foreign rivals, thus creating a level playing field in international commerce").

18. See supra note 4 and accompanying text. 
their domestic and regional competitors. This is the world the multinationals eventually got, starting in the United Kingdom and Germany. ${ }^{19}$

This Article argues that this private business interest-group account explains observed global patterns of enactment and enforcement of foreign anticorruption laws better than existing explanations grounded in altruism, governmental interests, or international institutional analysis. This account also enables us to make better predictions about future trends in foreign anti-corruption laws than the alternative theories. Specifically, our interest-group explanation allows us to make two concrete predictions regarding enactment and enforcement patterns going forward.

Countries are more likely to adopt and enforce foreign anti-corruption laws on businesses operating within their borders once multinational businesses based in those jurisdictions face significant risks of enforcement in other jurisdictions, such as the United States or the United Kingdom. This leads to a critical implication for the fight against global corruption: the best way to get countries to enact and enforce foreign anti-corruption laws is to enforce your own anti-corruption laws against their companies. In other words, the best way to get France to enforce its Law on Transparency, Combating Corruption and Modernization of Economic Life, commonly referred to as "Sapin II," ${ }^{20}$ is to enforce the FCPA or the U.K. Bribery Act against French multinationals.

Countries with few or no multinational corporations and therefore no realistic extra-territorial enforcement risk will be relatively immune to pressure from foreign anti-corruption laws. Even if such a jurisdiction were to enact such laws, insofar as businesses operating within it are not subject to an appreciable threat of extra-jurisdictional enforcement, there will be no real incentive for that country to enforce its own foreign anti-corruption laws. Foreign anti-bribery laws, in other words, are the supply-side solution to a first-world problem: multinational companies paying big bribes abroad. They may fail to solve the problem of bribes paid by companies beyond the reach of first-world enforcement.

But the lens of an international relations theory shows a way that the global anti-corruption norm might yet prevail. "Hegemonic stability theory" examines the conditions under which a global hegemon might provide a public good that benefits all nations, like free trade or a corruption-free international economic order. ${ }^{21}$ A variant on the theory posits that a critical mass of leading countries that are enforcing foreign corruption laws, known as a "k-group," might also jointly provide a public good under certain conditions. ${ }^{22}$ It may be the case that we are witnessing the formation of a hegemonic k-group of states forming around a global anti-corruption regime - the United States, Brazil, and Western European nations.

The presence of a foreign anti-corruption k-group of capital-exporting countries may change the incentives in capital-importing states in the following

19. See infra Part V.

20. See infra Part V.

21. See infra Section IV.D.1.

22. See infra Section IV.D.1. 
way. Imagine a government official in a capital-importing country who is considering taking a bribe in awarding the contract for a large infrastructure project. Companies from the k-group will not pay bribes, fearing enforcement of foreign anti-corruption laws; companies from non-k-group countries will pay bribes. But if the official accepts a bribe and awards a contract to a non-k-group company, he or she will have to explain why the bids from k-group companies were rejected. Insofar as k-group companies may be viewed as offering higher-quality work than non-k-group companies, this may be a difficult decision for the official to rationalize. In other words, if the traditional competitors of American companies-British, German, and French companies with good reputations-are no longer willing to offer bribes, the official will have a harder time explaining why he or she awarded the contract to a less established company from a country that still does not enforce foreign anti-corruption laws. This realignment of demandside incentives on the part of potential bribe recipients will only increase as the k-group spreads due to supply-side incentives.

China is a wild card in both stories. Because many of its international businesses are state-owned or state-influenced, China may be immune to the business-interest incentive story we are telling. In other words, because our model depends upon the incentives of private business interests - interests that are not as pronounced in China given the role of the Chinese state in enterprise-it does not allow us to venture a strong prediction regarding China. And to the extent that China commands a large share of international business contracts, the willingness of its state-owned or state-influenced companies to bribe may suffice to counteract the anti-corruption norm of the k-group. It is possible that we are headed toward a world of dueling hegemons.

This Article proceeds as follows. Part II highlights important conceptual distinctions between foreign versus domestic corruption and why eliminating foreign corruption became a global policy priority. Part III develops our interestgroup causal story, tracing the path of enactment and enforcement of the FCPAthe first and most prominent national foreign anti-corruption law-through the lens of domestic business interests. The U.S. business community's successful lobbying for multilateral treaties to "level the playing field," which culminated in the OECD Convention, is a key part of this story. Part IV surveys existing literature and explanations for the rise of foreign anti-corruption laws. It then introduces our contending explanation which brings in international relations theory by applying hegemonic stability theory and its offshoot k-group theory to explain evolving patterns in the enactment and enforcement of foreign anti-corruption laws. Part IV also offers predictions on the future trajectory of laws in this area as well as a framework that can be applied to other international legal contexts. Part V then tests our explanation against observed patterns in the enactment and enforcement of foreign anti-corruption laws in other countries in the wake of the OECD Convention. A brief conclusion follows. 


\section{Why Do We CARE ABOUT FOREIGN CORRUPTION?}

Political scientist Joseph Nye defined corruption as "behavior which deviates from the formal duties of a public role because of private-regarding (personal, close family, private clique) pecuniary or status gains . . ."23 Corruption has long been perceived as detrimental to good domestic governance, especially in liberal democratic countries like the United States. ${ }^{24}$ Government receipts and revenues are diverted from uses of greatest benefit to the public in favor of suboptimal uses sought by bribe-payers. ${ }^{25}$ For instance, a public official who takes a bribe may award a government contract to an inexperienced builder or let a criminal go free to commit more crimes. Those who do not bribe, whether because of integrity or a lack of resources, may lose meritorious bids, receive second-class treatment, or suffer generally from degraded public services. Additionally, bribes often entail falsified accounting records by both the taker and the giver of a bribe. Such subterfuge contributes to a lack of transparency that imposes transaction costs to monitor and police, and it may distort public policy decisions if widespread. Hence, most countries have longstanding domestic antibribery laws, and domestic political orders have routinely - if episodicallyprosecuted egregious cases of domestic corruption. ${ }^{26}$

In the post-World War II, post-colonial era, however, opinions among economists and political scientists regarding the relative benefits of corruption in the international — as opposed to domestic — order became divided. ${ }^{27}$ The animating concern was that it seemed unrealistic to expect impeccable public-regarding conduct from officials in post-war or post-colonial developing nations with weakened or fledgling governance institutions. In this context, it seemed moralistic and even counter-productive to condemn governments as "corrupt"a charge leveled against newly installed ruling regimes not only by rueful former colonial powers but also by indigenous contenders for power. From the perspective of macroeconomic theory, corruption might have a net positive effect on growth in a developing country if the size of the public pie in the country grew despite greater marginal growth for those in power taking bribes. At the level of petty officials in such countries, graft supplied an essential supplement to the meager public salaries developing countries could provide. ${ }^{28}$ Furthermore, some

23. J. S. Nye, Corruption and Political Development: A Cost-Benefit Analysis, 61 AM. PoL. SCI. R. 417, 419 (1967).

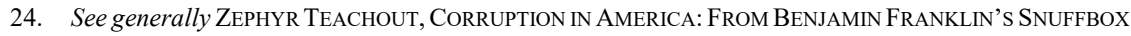
TO CITIZENS UNITED (2016).

25. See, e.g., Norimitsu Onishi \& Selam Gebrekidan, Hit Men and Power: South Africa's Leaders Are Killing One Another, N.Y. TIMES (Sept. 30, 2018), https:/www.nytimes.com/2018/09/30/world/africa/south-africa-anc-killings.html (detailing rampant corruption involving government contracts in South Africa that has sparked assassinations against whistleblowers). The article details one particularly egregious instance of corruption involving the refurbishment of a historic building in a South African province. Id. ("after five years and more than $\$ 2$ million in public money, the project was a sinkhole of dubious spending, with little to show for it").

26. See Susan Rose-Ackerman, Corruption and Government: Causes, Consequences, And REFORM (2012).

27. See John Brademas \& Fritz Heimann, Tackling International Corruption: No Longer Taboo, 77 ForEIGN AFF. 17, 21 (1998).

28. See Nye, supra note 23 , at 427 . 
economists viewed bribes as necessary grease to get things done in countries with copious laws and regulations on paper that might be invoked to block beneficial investments or economic activity. ${ }^{29}$

In the past couple decades, however, consensus has formed that corruption in the developing world has net negative effects that are worth eradicating. ${ }^{30} \mathrm{In}$ deed, some contemporary voices go so far as to condemn corruption as "an unrecognized threat to international security." ${ }^{\prime 1}$ The notion that there should be different standards for domestic corruption as between developed and developing countries was always problematic. ${ }^{32}$ The same economic arguments about inequity, inefficient allocation of public resources, and lack of transparency and transaction costs are valid in all domestic political orders, regardless of the relevant order's state of economic development. What changed, then? As the imperatives of the Cold War ended and the colonial era faded into history, the paternalistic instinct to condone anti-corruption measures in the developing world also faded. At the same time, the demise of superpower rivalry opened the possibility of fully global cooperation toward public goods, like free trade or the eradication of corruption.

Consequently, a global norm against corruption was promulgated on the international plane. Multilateral treaties like the OECD Convention of 1998 and the U.N. Convention against Corruption of 2005 are the formal international law manifestations of the norm. These treaties, among other things, require signatory nations to pass domestic laws creating civil and criminal liability for the payment of foreign bribes. At the same time, international financial institutions like the World Bank and the regional development banks made anti-corruption initiatives a priority and a condition for sponsored development projects. ${ }^{33}$ In this way, soft law complemented hard law on the international level.

The germinal insight behind the global anti-corruption movement is that a corruption-free world order is a public good, analogous to a free-trade world without tariffs. ${ }^{34}$ Public goods, however, are not so easy to achieve despite the common benefit of all, as witnessed by the centuries it took to establish a global near-free-trade regime and the threats to it even at present. This is in part because no one country can be assured of capturing enough of the benefit to make the first move to attain it. Moreover, the countries bearing the most costs for providing the public good have an incentive to defect out of resentment against others'

29. See Brademas \& Heimann, supra note 27, at 17.

30. See id. at 18; James Wolfensohn, President, World Bank, Address to the Board of Governors at the Annual Meetings of the World Bank and the International Monetary Fund (Oct. 1, 1996).

31. Carnegie Endowment for InT'L Peace Working Group on Corruption and Security, CORRUPtion: The UnRECOGNIZED THREAT TO INTERNATIONAL SECURITY (2014), http://carnegieendowment.org/files/corruption_and_security.pdf.

32. Id. at 3-4.

33. See Wolfensohn, supra note 30

34. A public good is non-rivalrous (more than one person can consume the good at the same time) and non-excludable (i.e., non-payors for the good cannot be denied access to it). See generally Tyler Cowen, Introduction to Public Goods \& Market Failures: A Critical Examination 1, 3-4 (Tyler Cowen ed., Transaction Publishers 1999). Paradigmatic examples of public goods are lighthouses and national defense. See R.H. Coase, The Lighthouse in Economics, 17 J.L. \& ECON. 357, 358 (1974). 
free-riding. With specific respect to global anti-corruption, a government, despite its interest in combating corruption at home, has an incentive to defect from laws barring bribes in foreign countries paid by its own companies to secure lucrative international business contracts and resultant foreign revenues. Without the bribes, companies from other countries would obtain the contracts. The predictable outcome of this collective action problem is that any effort to build a global anti-corruption regime is doomed to failure. Yet this regime appears to be forming, presenting an interesting puzzle to be explained.

To summarize, Part II makes two important conceptual points about foreign anti-corruption laws. First, the oddity of laws outlawing foreign corruption as opposed to the obvious justification and ubiquity of domestic anti-corruption laws is often overlooked. The latter is intuitive; the former is not. Understanding the differing incentives between the two is essential to perceiving the puzzle and grasping our solution. Second, many people forget that for most of the postWorld War II period, economists and policymakers viewed foreign corruption in developing and rebuilding states as something to be tolerated or even as a good thing. It is only with the end of the Cold War in the 1990s that a consensus has formed that corruption anywhere is bad, and that a corruption-free world is an achievable and desirable public good.

\section{A History OF THE ENACTMENT AND ENFORCEMENT OF FOREIGN ANTI- CORRUPTION LAWS}

\section{A. Foreign Policy and the Genesis of the FCPA}

The genesis of foreign anti-bribery law was the Watergate scandal in the United States. The notorious break-in to Democratic Party headquarters by operatives working for President Richard Nixon's reelection campaign was discovered to have been financed by secret slush funds. Further investigation into the Watergate scandal revealed that such funds were not limited to domestic political uses. ${ }^{35}$ Specifically, investigations led to the discovery of U.S. corporate slush funds used to finance bribes and contributions to officials and politicians in foreign countries for favorable business treatment. ${ }^{36}$ These disclosures spurred a worldwide backlash against American corporations and the evils of U.S.-led market capitalism that damaged U.S. allies and empowered its adversaries during the Cold War. The FCPA emerged as an instrument of American foreign policy in response to this backlash.

In 1973, the U.S. Senate's Watergate hearings revealed that American corporations had made illegal payments into the President's reelection campaign, leading the SEC Director of Enforcement to launch an inquiry into how compa-

35. See Stanley Sporkin, The Worldwide Banning of Schmiergold: A Look at the Foreign Corrupt Practices Act on its Twentieth Birthday, 18 Nw. J. INT’L. L. \& Bus. 269, 272 (1998).

36. See id. at 271-72. 
nies recorded these payments. The inquiry found that companies had intentionally concealed the payments by falsifying their financial statements. ${ }^{37} \mathrm{An}$ expanded SEC investigation then found that not only were the mislabeled accounts used for making illegal political contributions, they were also being used to make other illegal payments, including bribes to foreign officials. ${ }^{38}$ In addition to the SEC's investigation, Congress itself convened a series of public hearings on the matter, most notably the Senate Foreign Relations Subcommittee on Multinational Corporations, chaired by Senator Frank Church. ${ }^{39}$ The Church Committee ultimately discovered that "over 400 U.S. companies admitted making questionable or illegal payments in excess of $\$ 300$ million to foreign government officials, politicians and political parties.

These revelations embarrassed prominent U.S. companies and soured sensitive U.S. relationships and negotiations with foreign nations. Lockheed Corporation, for example, was embroiled in scandal following revelations that it had bribed numerous foreign politicians and members of government, including officials in Italy and Japan, to win procurement contracts. ${ }^{41}$ The Lockheed revelations brought down the government of Prime Minster Tanaka in Japan. ${ }^{42}$ "Both Chilean President Allende and Venezuelan President Perez broke off talks with U.S. officials on compensation for nationalized property when they learned of corporate payments [by U.S. companies]. ${ }^{93}$ Congress and the American public were concerned that the disclosures not only revealed the excesses of U.S. capitalism but also risked undermining foreign allies facing Communist opposition. ${ }^{44}$ Congress enacted the FCPA to address and neutralize the adverse foreign policy consequences of U.S. companies' payments of foreign bribes.

37. Id. at 271 ("The political contributions were disguised on the contributing corporations' books and records. At no time did the books and records disclose that an illegal political contribution had been made. This was not an oversight; it was the product of careful planning by top corporate officials ....").

38. SEC, Report of the Securities and Exchange Commission on Questionable and ILlegal CORPORATE PAYMENTS AND PRACTICES 3 (1976), https://www.sec.gov/spotlight/fcpa/sec-report-questionableillegal-corporate-payments-practices-1976.pdf. ("The staff discovered falsifications of corporate financial records, designed to disguise or conceal the source and application of corporate funds misused for illegal purposes, as well as the existence of secret 'slush funds' disbursed outside the normal financial accountability system.").

39. Political Contribution to Foreign Governments: Hearings Before the Subcomm. on Multinational Corp. of the S. Comm. On For. Rels., 94th Cong. 2 (1975) (statement of Sen. Frank Church, Chairman, Subcomm. On Multinational Corp.) [hereinafter Church Committee].

40. H.R. REP. No. 95-640, at 4 (1977) (Conf. Rep.) (further noting that those acknowledging illegal or questionable payments included 117 companies in the Fortune 500).

41. The disclosures were particularly newsworthy because Lockheed was the beneficiary of a $\$ 200$ million bail-out by the U.S. government in 1971 to avoid bankruptcy. See Anthony Sampson, Lockheed's Foreign Policy: Who, in the End, Corrupted Whom?, N.Y. MAG., Mar. 15, 1976, at 53, 56, 58. Additional allegations involved payments to ruling-party politicians in West Germany, and to members of the Saudi and Dutch royal families.

42. See Foreign Payments Disclosure: Hearing on H.R. 15481 and H.R. 13870 Before the Subcomm. on Consumer Prot. and Fin. of the H. Comm. on Interstate and Foreign Com., 94th Cong. 2 (1976) (statement of Rep. John. M. Murphy, Chairman, Subcomm. On Consumer Prot. and Fin.).

43. Unlawful Corporate Payments Act of 1977: Hearing on H.R. 3815 Before the Subcomm. on Consumer Prot. and Fin. of the H. Comm. On Interstate and Foreign Com., 95th Cong. 169 (1977) (statement of Rep. Michael Harrington).

44. See Church Committee, supra note at 39 . 
The FCPA targets both bribery and bad accounting. It prohibits bribesthe giving of anything of value with a corrupt intent — paid to foreign officials as well as the failure to keep books and records that accurately reflect the disposition of company assets. ${ }^{45}$ The FCPA is unprecedented: it is the first law to criminalize the payment of bribes to officials in a foreign country. It is remarkable that the U.S. chose to act unilaterally to prohibit what was widely known to be a common practice worldwide; indeed, foreign bribes were treated as tax-deductible business expenses in many countries. It was, accordingly, a problem that the U.S. could not solve alone. ${ }^{46}$ Even more remarkable is the willingness of the U.S. government to act despite the fact that doing so threatened to put American businesses at a disadvantage in competing for lucrative international business contracts. ${ }^{47}$ Why would elected representatives disregard domestic business interests in a quixotic effort to prevent bribery in foreign countries?

The initial enactment of the FCPA reflected the temporary subordination of business interests to foreign diplomacy and balance-of-power calculations during the fraught times of the Cold War. Senator Church made the point crystal clear in the opening statement of his subcommittee's investigation: "This subcommittee is concerned with the foreign policy consequences of these payments by U.S.-based multinational corporations." 48 Underscoring the point, the Senator read an extended quotation into the record from a book emphasizing the Communist dogma that "capitalism breeds corruption" and emphasizing that "the elimination of corruption has been advanced as the main justification for military

45. 15 U.S.C. $\$ \S 78 \mathrm{~m}, 78 \mathrm{dd}-1,78 \mathrm{dd}-2,78 \mathrm{dd}-3$, 78ff (2018). An important difference between the two parts of the statute is that the bribery aspect requires intent, but the books and records part is strict liability. Because the two often go together in practice, however, the books and records aspect of the statute eventually became a tool of prosecutors, excusing them of the difficulty of proving intent.

46. See, e.g., Protecting the Ability of the United States to Trade Abroad: Hearing on S. Res. 265 Before the Subcomm. on Int'l Trade of the S. Comm. on Fin., 94th Cong. (1975) (statement of Sen. Abraham Ribicoff, Chairman, Subcomm. On Int'l Trade) (“[A]nybody who knows what is going on worldwide knows this is a worldwide phenomenon; that business houses and business corporations in every nation of the world are paying under the table and are guilty of bribes but none of them paint them this way."); Lockheed Bribery: Hearing Before the S. Comm. on Banking, Hous., and Urban Affairs, 94 Cong. 27-28 (1975) (statement of D.J. Haughton, Chairman of the Board, Lockheed Aircraft Corp.) (acknowledging payments to foreign officials but emphasizing that "so did everyone else who was at all knowledgeable about foreign sales" because "it appeared to be necessary to make such payments in order to compete successfully in many parts of the world.").

47. See, e.g., Abuses of Corporate Power: Hearing Before the Subcomm. on Priorities and Econ. in Gov't of the Joint Econ. Comm., 94th Cong. 153-54 (1976) (statement of Robert S. Ingersoll, Deputy Secretary of State) ("There is widespread recognition in the Congress that such unilateral action [on corporate payment of foreign bribes] would put U.S. companies at a serious disadvantage in the export trade."); Unlawful Corporate Payment Acts of 1977: Hearing on H.R. 3815 and H.R. 1602 Before the Subcomm. on Consumer Prot. and Fin. of the H. Comm. on Interstate and Foreign Commerce, 95th Cong. 164 (1977) (statement of Rep. John E. Moss, Member, H. Comm. on Interstate and Foreign Commerce) (emphasizing that "to think that no loss of business would occur in every instance would be unrealistic. Can we allow this to occur? Yes, if that is the small price we must pay to return morality to corporate practice."); Id. at 187-88 (statement of W. Michael Blumenthal, U.S. Secretary of the Treasury) ("[A]ll right, we will be at a slight competitive disadvantage and we will all sleep better for it.").

48. Church Committee, supra note at 39; see also Mike Koehler, The Story of the Foreign Corrupt Practices Act, 73 Оніо Sт. L.J. 929, 932-43 (2012) (describing how foreign policy concerns motivated the passage of the FCPA). 
takeovers." 49 Over the course of many hearings in both houses of Congress focusing on foreign bribes paid by U.S. corporations, speakers repeatedly emphasized that foreign bribery weakened U.S. allies and strengthened U.S. enemies. ${ }^{50}$ Bribery was linked to Communist Party gains in Italy, ${ }^{51}$ the fall of pro-U.S. governments in Honduras and Libya, ${ }^{52}$ and political difficulties facing allied governments in Japan, the Netherlands, and elsewhere around the world. ${ }^{53}$ An anti-corruption backlash leading to the downfall of friendly governments is an omnipresent trope in the legislative history. Senator Church summed it up nicely: "The Communist bloc chortles with glee at the sight of corrupt capitalism." 54

49. Church Committee, supra note at 39, at 2-3 (quoting GUNNAR MYRDAL, ASIAN DRAMA: AN INQUIRY INTO THE POVERTY OF NATIONS (1968)).

50. See, e.g., Abuses of Corporate Power: Hearing Before the Subcomm. on Priorities and Econ. in Gov't of the Joint Econ. Comm., 94th Cong. 154 (1976) (statement of Robert S. Ingersoll, Deputy Secretary of State) ("Preliminary results have included serious political crises in friendly countries . . . Many foreign commentators and opinion makers have expressed concern about the effects of U.S. processes in their countries and suggested that the United States has a responsibility to take into account the interests of its allies when it is cleaning up its own house."); The Activities of American Multinational Corporations Abroad: Hearing Before the Subcomm. on Int'l Econ. Policy of the H. Comm. on Int'l Relations, 94th Cong. 22-23 (1975) (statement of Mark B. Feldman, Deputy Legal Advisor, Department of State) ("The head of a friendly government has been removed from office and other friendly leaders have come under political attack [because of bribery revelations].").

51. The Activities of American Multinational Corporations Abroad: Hearing Before the Subcomm. on Int'l Econ. Policy of the H. Comm. on Int'l Relations, 94th Cong. 1-2 (1975) (statement of Rep. Robert N.C. Nix, Chairman, Subcomm. on Int'l Econ. Policy) (noting among other things that "the Communist party is using the fact of multinational bribery in Italy against the political friends of the United States.").

52. Id. at 4 (statement of Rep. Stephen J. Solarz, Member, Subcomm. on Int'1 Econ. Policy) ("One government has already been toppled and political parties in several other countries have been seriously compromised."). In the words of Senator Church:

There is also little doubt that widespread corruption serves to undermine those moderate democratic and pro-free-enterprise governments which the United States has traditionally sought to foster and support. Several oil companies testified before the subcommittee that they had made huge political contributions in Italy and Korea, for example. They claimed to be supporting the democratic forces who are friendly to foreign capital in those countries, but in fact, they were subverting the basic democratic processes of those two countries by making illegal contributions and were, at the same time, providing the radical left with its strongest election issue. The large and steady gains made by the Italian Communist Party in recent elections are due in no small part to the fact that it is believed to be the only non-corrupt political force in the country, while the other parties are seen as the handmaidens of foreign and domestic financial interests.... [Such practices] only serve to discredit them and the United States. Ultimately, they create the conditions which bring to power political forces that are no friends of ours, whether a Quaddafi in Libya, or the Communists in Italy.

Protecting the Ability of the United States to Trade Abroad: Hearing on S. 265 Before the Subcomm. on Int'l Trade of the S. Comm. on Fin., 94th Cong. 9 (1975) (statement of Sen. Frank Church, Chairman, Subcomm. on Multinational Corp.).

53. Foreign Payments Disclosure: Hearing on H.R. 15481 and H.R. 13870 Before the Subcomm. on Consumer Prot. and Fin. of the H. Comm. on Interstate and Foreign Commerce, 94th Cong. 2 (1976) (statement of Rep. John M. Murphy, Chairman, Subcomm. on Consumer Prot. and Fin.) ("The foreign policy implications for the United States are staggering and in some cases, perhaps irreversible. Payments by Lockheed alone may well have advanced the Communist cause in Italy. In Japan, a mainstay of our foreign policy in the Far East, the government is reeling as a consequence of such payments. On August 16, former Prime Minister Tanaka was indicted on charges of accepting \$1.7 million from Lockheed. And most recently, the monarchy in the Netherlands has been rocked by the Lockheed scandal. All of this lends substantial credence to the suspicions by extremists that U.S. businesses operating in their country have a corrupting influence on their political systems.").

54. 122 CONG. REC. 12,604-05 (1976) (statement of Sen. Church). 
Given these broad geostrategic aims, the statute Congress and President Carter passed was not the narrow corrective to corporate accounting and bookkeeping favored by the more business-conscious SEC. ${ }^{55}$ In outlawing the payment of foreign bribes, Congress went further, guided more by the Church Committee's Cold War strategic vision than the SEC's original investigation and its narrower corporate responsibility and sound business ethics aims. By criminalizing the payment of foreign bribes, Congress sought to make a strong statement against American instigation of corruption abroad. The ultimate aim was to buttress friendly governments and to deny succor and rhetorical force to Communist movements around the world that had zeroed in on U.S. corporate payments to fuel anti-capitalist, anti-American sentiment. The FCPA, in other words, was a political weapon of the Cold War, wielded in the interests of national security.

\section{B. Business Interests Intervene}

U.S. businesses with foreign operations and their lobbyists could not stop the FCPA from being adopted given the perceived national security interests behind the statute's enactment. Indeed, they hardly tried. The American Chamber of Commerce and a special committee of the New York City Bar did testify that while bribery of foreign officials was abhorrent, new legislation was not necessary because existing law was sufficient to deal with the problem. ${ }^{56}$ Although some members of Congress were sympathetic to this view, ${ }^{57}$ and others were concerned that unilateral action would put U.S. businesses at a competitive disadvantage ${ }^{58}$ these arguments could not overcome the momentum in favor of the

55. The Activities of American Multinational Corporations Abroad: Hearing Before the Subcomm. on Int'l Econ. Policy of the H. Comm. on Int'l Relations, 94th Cong. 189 (1975) (statement of Philip A. Loomis, Jr., Commissioner, SEC) ("[O]ur obligation . . . is to obtain disclosure of information which is material to investors in the buying and selling of securities in the company. We are not here to police the morality of American industry as such, but the responsibilities of disclosures to investors.").

56. See Foreign Corrupt Practices and Domestic and Foreign Investment Disclosure: Hearing on S. 305 Before S. Comm. on Banking, Hous., and Urban Affairs, 95th Cong. 185-86 (1977) (statement of J. Jefferson Staats, Staff Associate, Chamber of Commerce of the United States) ("The Chamber condemns the payment ... of bribes .... [But] U.S. securities law already requires public disclosure of material payments .... It is important to note, as well, that misrepresentations to the Internal Revenue Service of certain payments may constitute violations of the Internal Revenue Code. The Chamber, therefore, is not convinced that new legislation is needed to confront the problems caused by questionable overseas business payments."); Foreign Payments Disclosure: Hearing on H.R. 15481 and H.R. 13870 Before the Subcomm. on Consumer Prot. and Fin. of the H. Comm. on Interstate and Foreign Commerce, 94th Cong. 178 (1976) (statement of William F. Kennedy, CoChairman, Special Comm. on Foreign Payments, Ass'n of the Bar of the City of New York) ("There was never a lack of law applicable to the situation. What there was, was a lack of law enforcement.").

57. Foreign Payments Disclosure: Hearing on H.R. 15481 and H.R. 13870 Before the Subcomm. on Consumer Prot. and Fin. of the H. Comm. on Interstate and Foreign Commerce, 94th Cong. 147 (1976) (statement of Rep. Michael Harrington) ("I feel very strongly that the existing legislation is adequate.").

58. Protecting the Ability of the United States to Trade Abroad: Hearing on S. 265 Before the Subcomm. on Int'l Trade of the S. Comm. on Fin., 94th Cong. 1 (1975) (statement of Sen. Abraham Ribicoff, Chairman, Subcomm. on Int'l Trade) (noting that once American companies were barred from making payoffs, "the business that they should be getting would be going to foreign competitors who were undertaking the same practices"). 
statute. Given that its preferred outcome of preventing the FCPA from being enacted was politically impossible, the business community took action toward a second-best outcome: pursuing the twin goals of a level playing field internationally and lax enforcement domestically.

The U.S. government's efforts to export the new foreign anti-corruption norm coincided with the conception of the FCPA. As early as 1975, the Senate passed a unanimous resolution urging the Executive Branch to raise anti-corruption initiatives in negotiations with trading partners. ${ }^{59}$ The U.S. did try to include anti-corruption measures in the Tokyo round of General Agreement on Tariff and Trade (GATT) negotiations (1973-1979), but the other GATT nations balked at treating corruption as a trade issue. ${ }^{60}$ The Senate Report on the FCPA also urged the Executive Branch to coordinate anti-bribery efforts with other capital-exporting nations through targeted multilateral or bilateral international agreements, although it did not make FCPA enactment contingent upon simultaneous international or foreign legal initiatives. ${ }^{61}$ The Executive Branch focused its ensuing global mobilization efforts in the 1970s on the OECD and the U.N.'s Economic and Social Council (ECOSOC).$^{62}$ Neither initiative bore much fruit. The OECD did agree to include a general anti-bribery statement in the 1976 Declaration on International Investment and Multinational Enterprises. ${ }^{63}$ But the other OECD countries would go no further because they did not share the United States' unique perception of foreign bribery as a national security threat. Rather, they continued to view it as an ordinary cost of doing business in the developing world. The U.N. initiatives did not even get as far as a statement of general principles due to Cold War divisions and disagreements about how to deal with apartheid in South Africa.

Unsure of the prospects for leveling the playing field by diplomacy or public international law, the U.S. business community also pursued private initiatives to spread the foreign anti-corruption norm within the global business community. As the U.S. moved to adopt the FCPA, the Paris-based International Chamber of Commerce ("ICC"), a business association promoting international trade and investment, promulgated a set of anti-bribery commitments that could be incorporated into cross-border contracts at the urging of U.S. business interests. ${ }^{64}$ Because the contractual language was not mandatory, however, the best

\footnotetext{
59. S. Res. 265, 94th Cong. (1975).

60. See Peter W. Schroth, The United States and the International Bribery Convention, 50 AM. J. ComP. L. 593, 596-97 (2002).

61. S. REP. No. 94-1031, at 6 (1976).

62. See Schroth, supra note 60, at 597-98.

63. Organisation for Economic Co-operation and Development [OECD], Declaration on International Investment and Multilateral Enterprises (May 25, 2011), http://www.oecd.org/daf/inv/investment-policy/oecddeclarationoninternationalinvestmentandmultinationalenterprises.htm.

64. INT'L CHAMBER COMMERCE COMM'N ON CORP. RESPONSIBILITY \& ANTI-CORRUPTION, ICC RULES ON COMBATING CORRUPTION (2011), http://www.iccwbo.org/advocacy-codes-and-rules/areas-of-work/corporateresponsibility-and-anti-corruption/ICC-Rules-on-Combatting-Corruption/. The mechanism for contractual incorporation was the ICC's form Anti-Corruption Clause. See INT'L CHAMBER COMMERCE ON CORP. RESP. \& ANTICORRUPTION, ICC ANTI-CORRUPTION ClAuSE (2012), http://www.iccwbo.org/Advocacy-Codes-and-Rules/ Document-centre/2012/ICC-Anti-corruption-Clause/.
} 
the ICC could do was encourage its members to opt in to anti-bribery commitments. Non-US businesses, aware of their advantages vis-à-vis their U.S. competitors, routinely chose not to make the commitment.

By 1981, the failure to mobilize a multilateral anti-bribery coalition that would relieve perceived disadvantages for U.S. businesses abroad caused the General Accounting Office ("GAO") to issue a report entitled The Impact of the FCPA on U.S. Business. ${ }^{65}$ The report was based on a survey of 250 of the largest U.S. companies and offered strong critiques of both the FCPA's accounting and substantive provisions ${ }^{66}$ The central criticism of the substantive anti-bribery provision was that it left American business at a competitive disadvantage to foreign competitors:

More than 30 percent of the questionnaire respondents engaged in foreign business reported they had lost overseas business as a result of the act. In addition, while more than 70 percent of the questionnaire respondents believed the act has been effective in reducing questionable foreign payments by American companies, over 60 percent of the respondents perceived that, assuming all other conditions were similar, American companies could not successfully compete against companies abroad that are not subject to the same prohibitions. ${ }^{67}$

The ultimate recommendation of the report was to push for "an effective international ban against bribery," emphasizing that most respondents "believed an international agreement would strengthen America's competitive position abroad." ${ }^{68}$ Noting that efforts at the United Nations had failed for four years in a row, the report closed by urging the President make "a strong international antibribery agreement" a priority as well as recommending that Congress demand an annual report of progress made toward that end. ${ }^{69}$ Nevertheless, foreign governments - lacking a coherent domestic interest group in favor of banning foreign bribery and, in many cases, harboring a clutch of companies that happily paid foreign bribes to win business - continued to resist. $^{70}$

65. U.S. Gov'T ACCOUnting OfF., B-198581, IMPaCt OF Foreign CORRuPt Practices ACt ON U.S. BUSINESS (1981), http://archive.gao.gov/d46t13/114503.pdf.

66. The basic criticism of the accounting provisions was that they were vague and generated excessive and inefficient compliance costs. About $55 \%$ of the respondents reported that their efforts to comply with the Act have resulted in costs that were greater than the benefits received. About half of these respondents believed the cost burden increased their accounting and auditing costs by $11-35 \%$. Another $20 \%$ estimated these costs increased by more than $35 \%$. Id. at 6 .

67. The Impact of the Foreign Corrupt Practices Act on U.S. Business: Hearing Before the Subcomm. on Int'l Fin. and Monetary Policy and Subcomm. on Sec. of the S. Com. on Banking, Hous., and Urban Affairs, 97 Cong. 4 (1981) (statement of Donald L. Scantlebury, Div. Dir. and Chief Accountant of GAO Accounting and Fin. Mgmt. Div.).

68. Id. at 45 .

69. Id. at 48 .

70. The American companies pointed out that some U.S. trading partners have explicitly encouraged such bribes by permitting businesses to claim them as tax-deductible business expenses. S. REP. NO. 105-277, at 2 (1998). The Commerce Department has stated that it has learned of significant allegations of bribery by foreign firms in approximately 180 international commercial contracts since mid-1994, contracts that were valued at nearly $\$ 80$ billion. Id. 
Despite the lack of success on leveling the playing field, American businesses did manage to achieve the second part of their second-best outcome: minimal enforcement of the FCPA within the U.S. itself. In the early years of the statute, neither the SEC nor the DOJ aggressively pursued cases involving foreign bribes. ${ }^{71}$ Although the SEC did pursue enforcement actions under the FCPA's accounting provisions, the agency brought only one action under the substantive anti-bribery provisions in the statute's first ten years. ${ }^{72}$ Likewise, the DOJ reported few bribery investigations, bringing only those cases that involved glaring violations of the law-substantial cash payments to senior foreign officials. ${ }^{73}$ By the late 1980 s, enforcement was effectively as moribund as any serious effort to forge an international agreement against bribery. ${ }^{74}$

Indeed, the domestic enforcement situation had reached such a nadir that business interests grew hopeful in 1988 for a repeal of the FCPA. ${ }^{75}$ Although Congress did not have the stomach to repeal the decade-old foreign anti-corruption statute, it did lighten the Act's burden by permitting specified foreign payments and providing an affirmative defense for "reasonable and bona fide expenditures." ${ }^{.76}$ At the same time, Congress doubled down on efforts to build a coalition of governments opposed to foreign bribery, expressly charging the President to "pursue the negotiation of an international agreement, among the members of the Organization of [sic] Economic Cooperation and Development, to govern persons from those countries concerning acts prohibited" under the FCPA. ${ }^{77}$ Towards this end, Congress required the President to report back annually on his efforts, as the GAO report had recommended in $1981 .^{78}$

Consequently, the U.S. approached the OECD in early 1989 to propose the creation of an ad hoc group to work towards creating a "binding obligation by members to enact... penalties to punish their nationals and corporations who commit bribery in connection with [international commercial] transactions." 79

71. See Related Enforcement Actions, DOJ, http://www.justice.gov/criminal-fraud/related-enforcementactions (last updated Feb. 22, 2019); SEC Enforcement Actions: FCPA Cases, SEC, http://www.sec.gov/spotlight/fcpa/fcpa-cases.shtml (last updated May 13, 2019).

72. See SEC Enforcement Actions: FCPA Cases, supra note 71. The SEC was somewhat more active in enforcing the accounting provisions. Over the same ten-year period, the SEC pursued 109 injunctive actions and 24 administrative proceedings under the accounting provisions. See id.

73. See Adam Fremantle \& Sherman Katz, The Foreign Corrupt Practices Act Amendments of 1988, 23 INT'L LAW. 755, 759 (1989).

74. See Elizabeth K. Spahn, Implementing Global Anit-Bribery Norms: From the Foreign Corrupt Practices Act to the OECD Anti-Bribery Convention to the U.N. Convention Against Corruption, 23 IND. INT'L \& CoMP. L. REv. 1, 1-6 (2013) (describing the United States' push for international anti-bribery efforts); Related Enforcement Actions, supra note 71.

75. Brewster, supra note 13, at 1656-57.

76. Foreign Corrupt Practices Act Amendments of 1988 § 5003(c), Pub. L. No. 100-418, 102 Stat. 1107, 1415 (codified as amended at 15 U.S.C. \& 78dd-1 (2018)); see also Fremantle \& Katz, supra note 73, at 767 ("Domestic concerns engaged in foreign business appear to have obtained in the 1988 amendments a modicum of relief from the more onerous of the antibribery provisions of the FCPA.").

77. Foreign Corrupt Practices Act Amendments of 1988, § 5003(d).

78. Id.

79. See Organisation for Economic Co-operation and Development [OECD], United States Proposal on the Issue of Illicit Payments, at 2, OECD Doc. C(89)49 (Mar. 22, 1989), https://www.justice.gov/sites/default/files/criminal-fraud/legacy/2013/12/16/united-states-proposal-on-the-issue-of-illicit-payments.pdf (noting 
These efforts ultimately bore fruit in the OECD's Convention on Combating Bribery of Foreign Public Officials in International Business Transactions (the "OECD Convention") discussed in greater detail below. ${ }^{80}$

\section{Multilateral Treaties and Ensuing Domestic Enactments}

In 1994, the OECD Council adopted the "Recommendation on Bribery in International Business Transactions"- - a U.S.-backed proposal urging member countries to take "effective measures to deter, prevent and combat the bribery of foreign public officials in connection with international business transactions" and to coordinate on bringing their domestic laws into conformity with respect to the bribery of foreign public officials. ${ }^{81}$ The Recommendation led to the establishment of the Working Group on Bribery in International Business Transactions. The Working Group, in turn, published a "Revised Recommendation on Combating Bribery in International Business Transactions" in 1997. ${ }^{82}$ In this stronger initiative, the OECD Council moved to outlaw foreign bribery in an "effective and co-ordinated manner" by opening negotiations on "an international convention to criminalise bribery." $" 83$

Pursuant to the Revised Recommendation, the OECD Convention was adopted and opened for signature by the end of $1997 .{ }^{84}$ The OECD Convention calls on all parties to make it a crime

for any person intentionally to offer, promise or give any undue pecuniary or other advantage, whether directly or through intermediaries, to a foreign public official, for that official or for a third party, in order that the official act or refrain from acting in relation to the performance of official duties, in order to obtain or retain business or other improper advantage in the conduct of international business. ${ }^{85}$

goal of creating "comparable national legal standards governing bribery in conducting international commercial transactions").

80. Organisation for Economic Co-operation and Development [OECD], Convention on Combating Bribery of Foreign Public Officials in International Business Transactions (2011), https://www.oecd.org/daf/antibribery/ConvCombatBribery_ENG.pdf [hereinafter OECD Convention].

81. Organisation for Economic Co-operation and Development [OECD], Recommendation of the Council on Bribery in International Business Transactions, at 2-3, OECD Doc. C(94)75/FINAL (July 11, 1994), http://www.oecd.org/investment/anti-bribery/anti-briberyconvention/1952622.pdf.

82. Organisation for Economic Co-operation and Development [OECD], Revised Recommendation of the Council on Combating Bribery in International Business Transactions, OECD Doc. C(97)123/FINAL (May 23, 1997).

83. Id. at 2-3. The agreed common elements of criminal legislation and related actions were outlined in the Annex to the Recommendation. Id. at 7-9.

84. OECD Convention, supra note 80 , at 6 . To date, the Convention has been adopted by 43 parties, including 34 OECD member countries and 9 non-member countries including Argentina, Brazil, Bulgaria, Colombia, Latvia, Russia, and South Africa. For the status of the convention, see OECD, OECD Convention on Combating Bribery of Foreign Public Officials in International Business Transactions: Ratification Status as of May 2017, http://www.oecd.org/daf/anti-bribery/WGBRatificationStatus.pdf (last visited July 22, 2019).

85. OECD Convention, supra note 80 , at 7 . 
It further calls on all adopting parties to assert territorial jurisdiction broadly to enforce the criminal prohibition, to the extent allowed by national legal and constitutional principles. ${ }^{86}$ It also directs extension of extraterritorial jurisdiction with respect to nationals consistent with applicable national laws. ${ }^{87}$ The U.S. ratified the OECD Convention and promptly enacted domestic legislation to implement the treaty. ${ }^{88}$

This required the U.S. Congress to amend the FCPA to extend its jurisdictional hook - an event with significant consequences for subsequent trends in the statute's enforcement. First, the amendments provided for jurisdiction over the acts of U.S. businesses and nationals in furtherance of unlawful payments that take place wholly outside the U.S. ${ }^{89}$ Second, the amendments clarified that territorial jurisdiction could be asserted over foreign actors as long as the chain of transactions touched and concerned the territory of the U.S. ${ }^{90}$ Third, the amendments eliminated a pre-existing disparity in penalties between U.S. nationals and foreign nationals employed by or acting as agents of U.S. companies. ${ }^{91}$ The latter had formerly been subject only to civil penalties. ${ }^{92}$ The Act abolished this restriction and subjected all employees or agents of U.S. businesses to both civil and criminal penalties, regardless of their nationality. ${ }^{93}$

The ratification of the OECD Convention led to a spurt of national enactments not just in the United States but in all signatory states. These national statutes, however, remained largely dormant for several more years outside of the United States. ${ }^{94}$ The lack of enforcement was due to the same concern that U.S.

86. Id. at 16

87. Id. at $16-17$.

88. International Anti Bribery and Fair Competition Act of 1998, Pub. L. No. 105-366, 112 Stat. 3302.

89. OECD, United States: Review of Implementation of the Convention and 1997 Recommendation 13 (1999), http://www.oecd.org/daf/anti-bribery/anti-briberyconvention/2390377.pdf [hereinafter Phase I Implementation Report] ("Prior to its amendment in 1998, the FCPA asserted only territorial jurisdiction In light of the requirements of the Convention, the FCPA has added a jurisdiction basis for acts committed abroad by U.S. nationals and businesses (nationality jurisdiction)."). Even before its amendment, it was not necessary, however, that the payment, gift, offer, or authorization itself have taken place in the United States, only that an act in furtherance have taken place. Thus, if two officials of a corporation, at least one of whom was in the United States, corresponded (by mail, fax, or E-mail) or spoke with each other over the telephone concerning a planned unlawful payment, that would be sufficient for the United States to assert jurisdiction, even if the payment itself, the official to be bribed, the person actually paying the bribe, and the money to be used to pay the bribe are all outside the territory of the United States. Id. at 13-15. This exercise of extraterritorial jurisdiction over U.S. businesses and nationals for unlawful conduct abroad was believed to be consistent with U.S. legal and constitutional principles. Specifically, Congress's power was justified under the constitutional grants of power to Congress to "regulate Commerce with foreign Nations" and to "define and punish ... Offenses against the Law of Nations." U.S. CONST. art. $1, \S 8$, cl. 3, 10.

90. The United States interprets "territory" broadly. It includes the actual territorial boundaries of the fifty States, as well as territories, possessions, and commonwealths. In addition, it includes areas within its territorial waters, aboard ships and airplanes flying under its flag, and aboard aircraft en route to the United States. The 1998 amendments expanded the FCPA to cover "any person." For non-U.S. nationals and non-U.S. companies, the amended FCPA requires that the person to be prosecuted actually have committed an act in furtherance of a bribe within the U.S. Phase I Implementation Report, supra note 89, at 13-14.

91. International Anti Bribery and Fair Competition Act of 1998, $\S 3$.

92. See 15 U.S.C. $\S 78 f f(c)(2)(A)$ (1994) (current version at 15 U.S.C. § $78 \mathrm{ff}(\mathrm{c})(2)(2018)$ ).

93. 15 U.S.C. $\S 78 \mathrm{ff}(\mathrm{c})(2)(2018)$.

94. See infra Part V. 
companies had expressed when the FCPA was enacted: business interests in the relevant states perceived that strictly enforcing the prohibition on bribes would disadvantage their efforts to obtain lucrative international business contracts. Governments were receptive to these concerns until very recently. As with enactment, the United States took the lead in the new trend toward enforcement of foreign anti-corruption laws, as Section III.D explains.

\section{A New Era of FCPA Enforcement}

As described above, although the U.S. adopted the FCPA in 1977, enforcement was minimal for its first several decades. According to a database of FCPA enforcement actions maintained by Stanford University, from 1977 through 2001 , there was a total of $52 \mathrm{FCPA}$ enforcement actions. ${ }^{95}$ Between 2001 through 2018, however, there were $516 .{ }^{96}$ Figure 1 below demonstrates this graphically. Not only have the numbers of enforcement actions increased, so have the size of settlements to those actions.

\section{FIGURE 1: FCPA ENFORCEMENT ACTIONS BY YEAR}

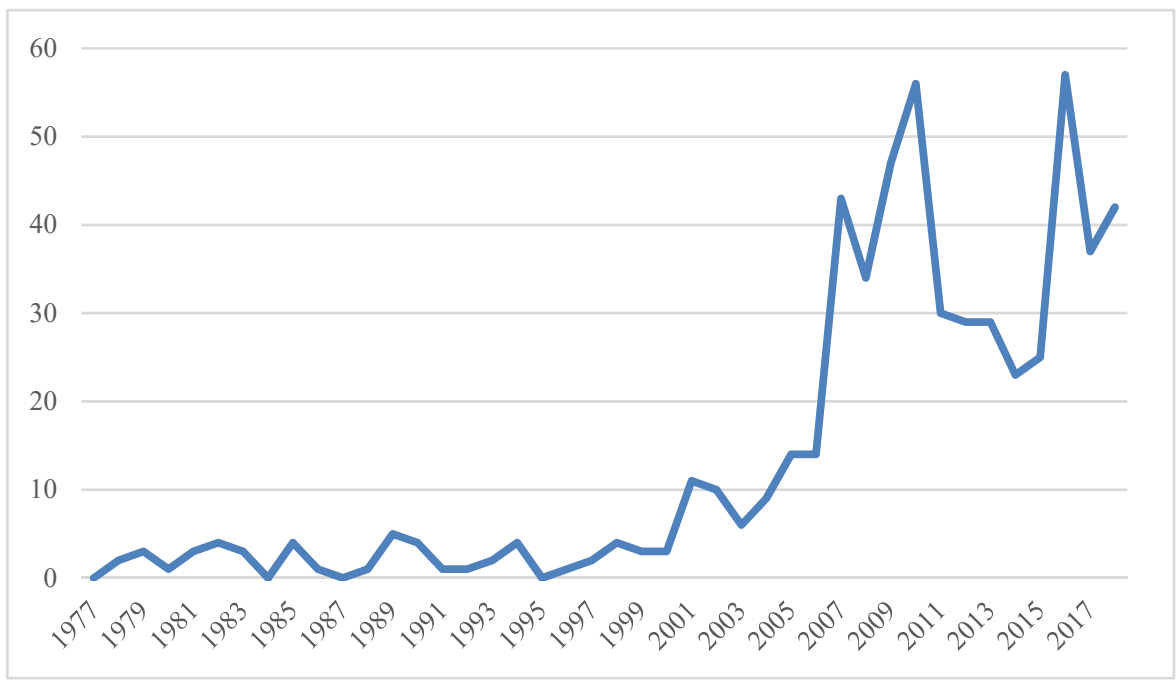

In other words, in the eighteen year period since 2001, there have roughly been ten times as many enforcement actions as there were in the twenty-four year period prior to 2001. Not only has the frequency of FCPA enforcement actions increased, so too have the size of settlements to those actions. As Professor Mike Kohler has observed:

The $\$ 1.8$ billion in combined corporate fines, penalties and disgorgement in 2010 is most striking when compared to 2000 FCPA enforcement. In 2000 , there was one FCPA enforcement action (by the SEC) with a total

95. See DOJ and SEC Enforcement Actions per Year, StANFORD LAW SCH.: Foreign CORRUPT PRACTICES ACt ClEARINGHOUSE, http://fcpa.stanford.edu/statistics-analytics.html (last visited July 22, 2019).

96. Id 
fine amount of $\$ 300,000$. The past decade has thus witnessed a remarkable transformation - not as to the FCPA itself (the statute has not changed since 1998), but as to FCPA enforcement and theories of prosecution. ${ }^{97}$

Additionally, the pattern of U.S. enforcement actions in the past several years has centered on foreign companies subject to FCPA jurisdiction under the post-OECD amendments by virtue of their operations or contacts with the United States. Stephen Choi and Kevin Davis reported that from 2004 through 2011, one third of all resolved enforcement actions involved non-US companies. ${ }^{98}$ They also found that the "SEC and DOJ impose greater sanctions, all else equal, on foreign companies." 99 Consistent with their analysis, a tally of the ten largest FCPA enforcement actions, as of September 2017, includes only three U.S. companies versus two French companies, and one each from Sweden, Germany, Israel, the U.K., and Holland. ${ }^{100}$ More recent data are in line with this trend: in 2016, one U.S. company (Och-Ziff), one Israeli company (Teva Pharmaceuticals) and one Brazilian company (Odebrecht/Braskem) paid FCPA settlements on the scale of the payments made by the top ten settlements that Choi and Davis reported. ${ }^{101}$ And on September 27, 2018, Petrobras, the Brazilian state-owned energy company, reached the largest bribe-paying settlement in history- $\$ 1.78$ billion to be paid to U.S. and Brazilian authorities, dwarfing the previous high of $\$ 800$ million paid by the German company Siemens in $2008 .{ }^{102}$ We will discuss in greater detail in Part IV the reasons for, and the ramifications of, this relatively recent trend in FCPA enforcement against foreign companies.

We believe that two factors explain the dramatic escalation in FCPA enforcement in 2001 and then in 2007. First, from a regulatory perspective, the passage of the OECD Convention and the amendments to the FCPA in its wake enhanced the legal instruments available for U.S. authorities to prosecute foreign corruption and raised the issue's profile. In particular, the significant rise in FCPA prosecutions after 2007 was anchored in the expansive jurisdictional reach of the statute owing to the 1998 amendments that allowed U.S. enforcement authorities to target the conduct of foreign companies, thereby sparing their superiors and themselves the political backlash that might come from markedly increased enforcement against U.S. businesses. At the same time, the multilateral treaty obligated the other capital-exporting countries that signed it to enact their own foreign corruption laws, raising the possibility of a level playing field for

97. Mike Koehler, Big, Bold, And Bizarre: The Foreign Corrupt Practices Act Enters A New Era, 43 U. ToL. L. Rev. 99, 104 (2011).

98. Stephen J. Choi \& Kevin E. Davis, Foreign Affairs and Enforcement of the Foreign Corrupt Practices Act, 11 J. EMPIRICAL LeGaL StUD. 409, 412 (2014).

99. Id. at 440 .

100. Richard L. Cassin, Telia Tops Our New Top Ten List (After We Do Some Math), FCPA Blog (Sept. 22, 2017, 7:28 AM), http://www.fcpablog.com/blog/2017/9/22/telia-tops-our-new-top-ten-list-after-we-dosome-math.html.

101. Richard L. Cassin, Reconsidered: Odebrecht and Braskem Are on Our FCPA Top Ten List, FCPA BLOG (Dec. 29, 2016, 8:18 AM), http://www.fcpablog.com/blog/2016/12/29/reconsidered-odebrecht-and-braskem-are-on-our-fcpa-top-ten-1.html.

102. Richard L. Cassin, Petrobras Reaches \$1.78 Billion FCPA Resolution, FCPA BLOG (Sept. 27, 2018, 9:28 AM), http://www.fcpablog.com/blog/2018/9/27/petrobras-reaches-178-billion-fcpa-resolution.html. 
U.S. businesses at risk of FCPA prosecution. And if enactments by other countries did not necessarily mean enforcement, the DOJ and SEC no longer had to fear active interference by foreign governments and could even invoke treatybased cooperation from them. Furthermore, having achieved the level playing field (at least on the books) that U.S. business interests had lobbied so strenuously for, U.S. enforcement authorities were emboldened to craft a more aggressive enforcement strategy. This shift in U.S. enforcement culture was enhanced by the enactment of the Sarbanes-Oxley Act and the accompanying onset of greater demands for corporate compliance and regulatory oversight. ${ }^{103}$

Second, from a geopolitical perspective, just as Watergate almost three decades earlier triggered the enactment of the FCPA because of the discovery of the role illicit corporate money played in the scandal, increasing awareness of the centrality of illegal money in laundering the proceeds of drug and other criminal enterprises and in terrorist financing focused attention on the FCPA as a powerful instrument for disrupting illegal cash flows. ${ }^{104}$ This was particularly true after the September 11th terrorist attacks, when U.S. and other anti-terrorism authorities focused on the flow of money to terrorist networks. ${ }^{105}$ Whether related to terrorism, drugs, or other crimes, illicit capital flows went through banks and were uncovered through an increased focus on anti-money laundering rules. ${ }^{106}$ Money laundering is a first cousin of bribery and corruption - the funds used for bribery are frequently laundered through shell businesses or sham transactions akin to the circulatory system for money laundering. Investigators naturally uncovered evidence of bribery once they started looking harder at money laundering and capital flows to terrorists, drug cartels, and rogue states. Having examined in detail the history of the enactment and enforcement of the FCPA, we turn in the next Part to theoretical explanations for the rise of foreign anti-corruption laws.

\section{CONTENDING ThEORIES OF ForeIGN ANTI-CORRUPTION LAWS}

Prior work on the development of foreign anti-bribery laws can be divided into three general approaches. The first takes human rights norms as the prime source of foreign anti-corruption laws. ${ }^{107}$ On this view, such laws are enacted to signify commitment to anti-corruption as a human or civil right. And, as with anti-discrimination law, enforcement of the anti-corruption norm occurs when

103. Brewster, supra note 13, at 1673-76.

104. DOJ \& SEC, A Resource Guide to the U.S. Foreign Corrupt Practices Act 2 (2012), https://www.sec.gov/spotlight/fcpa/fcpa-resource-guide.pdf.

105. Juan C. Zuarate, Treasury's War: The Unleashing of a NeW ERA of Financial Warfare 7 (2013). ("After September 11, 2001, the United States unleashed a counter-terrorist financing campaign that reshaped the very nature of financial warfare. The Treasury Department waged an all-out offensive, using every tool in its toolbox to disrupt, dismantle, and deter the flows of illicit financing around the world.").

106. Id. at 8-12.

107. See Spalding, supra note 11, at 1385-1402. 
the political and moral orders align to permit it. ${ }^{108}$ Second, the "realist" orientation focuses on the motivations of the states enacting and enforcing the legislation. The basic intuition is that a state will enact or enforce foreign anti-corruption laws when to do so is perceived to be in the state's national interest. Third, the "institutionalist" approach shares with the human rights view the basic idea that anti-corruption is a public good that needs to be advanced. Institutionalists, however, focus explanatory leverage on the design and workings of institutions: 1) on the international level, multilateral treaties (like the OECD Convention) and financial organizations (like the World Bank) for achieving the public good, and 2) on the domestic level, national laws (like the U.S. FCPA) and government agencies (like the SEC) and actors (like prosecutors).

All three explanations have much to contribute to understanding the history of the enactment and enforcement of foreign anti-corruption laws. Each explanation, however, fits only part of the story. Human rights based theories may explain why some capital-exporting states might wish to regulate foreign corruption in poor, developing countries, but they cannot explain how this interest overcomes the public goods problem. Such theories also fail to explain prevailing patterns of enforcement. Why, for instance, has the enforcement of foreign anticorruption laws accelerated so greatly since 2010 , despite a worldwide retrenchment in international human rights activism and a countervailing trend toward political authoritarianism and inward-looking nativism among developed countries? Similarly, theories emphasizing rent-seeking may explain some aspects of enforcement such as the recent trend toward large FCPA settlements against foreign companies. But they fail to account for the timing of enactments and worldwide patterns of enforcement beyond the United States. Both human rights and rent-seeking accounts also fail to explain the FCPA's dormancy from 1977 to 2000. Finally, institutionalist theories help us to understand the process and formal mechanisms by which enactment and enforcement happen, but they do not tell us how the key institutions form their preferences. For that, we believe, a deeper understanding of the interests, incentives, and causal influence of interest groups is necessary.

108. To illustrate the analogy to anti-discrimination law, consider that the U.S. civil rights revolution only happened after Brown v. Board of Education, 347 U.S. 483 (1954), and the passage of the Civil Rights Act of 1964, despite that the relevant formal law - the Civil War Amendments to the U.S. Constitution - were ratified in 1868. Notwithstanding an initial attempt at meaningful enforcement during Reconstruction, the United States was not ready to enforce the law on the books until a century later. Similarly, the enactment of the FCPA in 1977 did not result in meaningful widespread enforcement until 2000, after the end of the Cold War. See supra Section III.D. 


\section{A. Rights-Based Accounts}

One leading theory of foreign anti-corruption laws hypothesizes human rights norms as the prime cause. ${ }^{109}$ On this view, states are principally motivated by moral or altruistic aims. Rich nation-states know that corruption is corrosive not only to their own domestic political orders but also to those of other states, particularly poorer ones, and seek to eradicate corruption everywhere. This human rights orientation is shared and advanced by the World Bank and other global NGOs. ${ }^{110}$ All other things being equal, a human-rights theory would seem especially strong as an explanation for the enactment of domestic anti-corruption laws like the FCPA and multilateral anti-corruption treaties. Both are outcomes with high symbolic value and the potential to serve as focal points in reform efforts. In human rights accounts, business interests are characterized as profitmaximizing actors that the state needs to regulate, not the primary engines of anti-corruption norm enforcement, as we argue. Professor Spalding asserts, for instance, that tweaking the FCPA to ensure that its enforcement better aligns with human rights justice (e.g., paying fines forward to victims in developing countries), is a better path to "holding corporations liable for overseas rights abuses" than the Alien Tort Statute. ${ }^{111}$ He writes:

What the world needs now is a federal statute that holds both U.S. and foreign companies liable for overseas human rights abuses; a statute that contains an express congressional statement of extraterritorial application and rests on well-established principles of corporate liability.... That statue already exists. It is the U.S. Foreign Corrupt Practices Act. ${ }^{112}$

Professor Spalding is surely right that multinational corporations paying bribes is a part of the problem of global corruption. But our account frames corporations not as bad actors that need to be regulated. Rather, it focuses on how the transnational environment can align their interests to solve the public good problem. No company wants to pay bribes; they pay them because they fear that others will pay them instead and take their business.

\section{B. Realist Accounts}

A second theory for the spread of foreign anti-corruption regulation focuses more squarely on patterns in enforcement of domestic laws, not just their enactment or the ratification of treaties. On this view, what is driving greater enforcement is not an altruistic commitment to furthering human rights abroad but rather rent-seeking by governments who prosecute and sanction bribe-paying firms. ${ }^{113}$ The United States, in particular, has imposed very large sanctions on companies

109. See Murray \& Spalding, supra note 11; Spalding, supra note 11, at 1385-1402; Andrew Brady Spalding, The Irony of International Business Law: U.S. Progressivism and China's New Laissez-Faire, 59 UCLA L. Rev. 354, 370-88 (2011).

110. See Brewster, supra note 13; Wolfensohn, supra note 30, at 6 .

111. Spalding, supra note 11, at 1366-67.

112. Id. at 1367.

113. See Choi \& Davis, supra note 98 , at 414 . 
for alleged FCPA violations in the twenty-first century. ${ }^{114}$ It and other countries that have recently become more aggressive about enforcement typically do not return moneys collected to the state in which bribes occurred, instead depositing them into their own treasuries. ${ }^{115}$ This result suggests that the motive for prosecutions is not to advance the good of the country in which corruption took place but rather to levy a "bad act" tax on companies in the enforcing state.

In terms of U.S. FCPA enforcement, the targets of sanctions have increasingly been non-U.S. companies based in capital-exporting countries engaged in activities related to the United States. This suggests an additional, nationalistic dimension to rent-seeking by U.S. government agencies and prosecutors. This impression seems reinforced by the fact that often the connection of such activities to the United States has been exceedingly minimal. ${ }^{116}$

The trend to bigger fines against foreign companies - funds that are kept in the capital-exporting enforcement jurisdiction - appears to confirm the suspicion that growing foreign anti-bribery enforcement is not motivated by an altruistic desire to ameliorate the human rights conditions in capital-importing states. Professor Koehler suggests that the enforcement patterns indicate rent-seeking, pure and simple. ${ }^{117}$ And Professors Choi and Davis frame a model explaining enforcement trends by primary reference to the national interests of the enforcing states. ${ }^{118}$ Country $A$ will enforce foreign bribery laws against Country $B$ 's corporations if to do so is in Country $A$ 's national interest. The state and its institutions are the focal point of both explanations. But the predictions of those who posit national interest or rent-seeking as the principal explanation for enforcement patterns do not line up with facts on the ground, as we shall see in Part V. Why, for instance, have the principal targets of the U.S. government's largest FCPA investigations and settlements hailed from closely allied countries like the United Kingdom, Israel, and Germany? Why, by contrast, have Chinese companies not been subject to any FCPA sanctions until December 2018, and then only for a relatively small amount?

\section{Institutional Accounts}

A third group of commentators emphasizes institutions over altruism, national interests, or rent-seeking to explain the spread of global anti-corruption measures. The key actors and variables are the U.S. President, Congress, the SEC, the DOJ (particularly prosecutors), their foreign counterparts, domestic laws like the FCPA, and international treaties like the OECD Convention. Professor Rachel Brewster, for example, emphasizes "international resonance" in describing how enactment of the FCPA inspired the OECD Convention, which in turn triggered an amendment to the FCPA enabling U.S. prosecutors to pursue

\footnotetext{
114. See id.

115. See id.

116. See, e.g., Cassin, Petrobras Reaches \$1.78 Billion FCPA Resolution, supra note 102.

117. Koehler, supra note 97, at 129-31.

118. See Choi \& Davis, supra note 98 , at 410, 419-28.
} 
an "'international-competition neutral' enforcement strategy, investigating domestic corporations and their foreign rivals alike." 119 Institutionalist explanations like Professor Brewster's focus on state actors and how collective action at the international level feeds back to the domestic level. Our account, by contrast, starts with private actors and their ability to influence law-making at the state level.

\section{Our Interest-Group Model}

In this Section, we invoke international relations theory to build our interest-group model to explain patterns in enactment and enforcement of foreign anti-corruption laws. The primary causal actors in our model are business interest groups - not states, international organizations of states, or non-governmental organizations. In our view, states are not the prime cause but rather the fora in which interest groups interact to achieve their preferences. With respect to a global anti-corruption norm, we focus on how it might be achieved not from the top-down by states and state actors, but from the bottom-up by the linked acts and preferences of business groups. We do not claim that state actors have no role. Rather, our central claim is that state action is motivated principally by private actors in each state - namely, the business lobby. But how do private interests motivate state actors? And how, once motivated by private actors, do states coordinate with each other? For answers to these questions, we turn to international relations theory - in particular, hegemonic stability theory and the concept of two-level games.

\section{Hegemony to K-Group Theory}

As noted above, freedom from official corruption in cross-border transactions has the character of a public good. ${ }^{120}$ All participants in the international system - sovereign states and firms engaged in cross-border trade - would prefer to have the public good, but no state or firm has sufficient incentive to bring it about due to collective action and free-rider problems. If one state prevents its private companies from paying bribes to get lucrative international business contracts, the contracts (and any profits from them) will go to companies based in other states that permit bribe-giving. Without the ability to coordinate and punish defectors, each individual participant has an incentive to continue to bribe, especially if doing so is perceived as a source of competitive advantage.

Nevertheless, despite the structural roadblocks posed by the collective-action and free-rider dynamics, public goods are in fact supplied in the international economic system. For example, the world order has realized advances in free trade, stable mediums of financial exchange, effective property rights enforceable across borders, and a host of other preconditions for stability and aggregate growth in the international economic realm. How is this so?

119. Brewster, supra note 13, at 1612.

120. See Coase, supra note 34 and accompanying text. 
International relations theorists developed "hegemonic stability theory" to explain the provision of public goods in the global economy. ${ }^{121}$ Hegemonic stability theory focuses on the distribution of power. ${ }^{122}$ The earliest versions of the theory argued that a single hegemonic state is necessary to ensure provision of a public good in the international economy, such as economic stability or free trade. ${ }^{123}$ When a single superpower extracts sufficient benefit from international stability, it will expend effort to coordinate other states and tolerate occasional defections, thereby creating a stable international economic order. ${ }^{124}$ Under the original articulation of hegemonic stability theory, the provisions of public goods sufficient to support international economic cooperation could be expected only under conditions of true hegemony, i.e., the presence of a single hegemonic state. $^{125}$

Later versions of hegemonic stability theory focused on the role of other nonhegemons in creating or supporting international economic stability. ${ }^{126}$ These revisions to the theory drew upon Mancur Olson's insight that a small group of actors, numbering $k$ where $k>1$, may be able to overcome collective action and free-rider problems under two conditions. ${ }^{127}$ First, each member of the "k-group" must extract sufficient benefit from the public good to justify its investment in bringing the good about. ${ }^{128}$ Second, each member of the k-group must know that its defection from the collective order would result in the failure of the good to be produced. ${ }^{129}$ Applying these insights to international relations, theorists argued that a small k-group of states could provide the necessary conditions for international economic cooperation just as well as a single hegemon could. ${ }^{130}$

For a time after the end of the Cold War, it was believed that the United States and the European Union had sufficient leverage in the world economy to constitute a k-group. In 2007, political scientist Daniel Drezner asserted that:

121. See Robert Gilpin, The Political Economy of International Relations 72-92 (1987) (articulating the core elements of hegemonic stability theory and responding to critics).

122. See id.

123. Charles P. Kindleberger, THE World in DePREsSion: 1929-1939, at 298 (University of California Press 1986) (1971) (drawing parallels between the Pax Britanica and the Pax Americana to argue that a hegemonic power is necessary to overcome collective action problems among states).

124. See GILPIN, supra note 121, at 74 .

125. This raises the vexed question of how to measure and define hegemony. Theorists have offered definitions in absolute and relative terms focusing on whether one nation's GNP, volume of international trade, and volume of international borrowing and lending dominate all others or whether such measures predominate over others on a relative basis. For the purposes of this Article, we take Transparency International's lead in presuming that a country's share of global exports is a serviceable benchmark for gauging its power in the global economy.

126. See Robert Keohane, After Hegemony: Cooperation and Discord in the World Political ECONOMY 39, 46 (1984) (discussing the prospect for international economic coordination to arise among small groups of state actors in the absence of hegemony); David A. Lake, Leadership, Hegemony, and the International Economy: Naked Emperor or Tattered Monarch with Potential?, 37 INT'L STUD. Q. 459, 467 (1993) (critiquing and extending hegemonic stability theory).

127. Mancur Olson, The Logic of Collective Action 33 (1965).

128. Id.

129. Id.

130. Duncan Snidal, The Limits of Hegemonic Stability Theory, 39 INT'L ORG. 579, 599 (1985) (modeling the possibility of collective action in the absence of hegemonic leadership). 
[The United States and the European Union] are the only two entities that combine relatively large markets with relatively low vulnerability. As measured by aggregate size, the United States and the European Union both have economies over $\$ 10$ trillion at the end of 2003. The American and European shares of global merchandise trade are more than twice that of any other "candidate" great power. Using market exchange rates, both the United States and European Union are twice as large as Japan, the next biggest economy. When their market size is combined, the United States and the European Union are responsible for roughly 40 percent of global output, 41 percent of world imports, 59 percent of inward foreign direct investment, 78 percent of outward foreign direct investment, and 99 percent of global mergers and acquisitions. ${ }^{131}$

Presuming the validity of k-group theory and sufficient unity of interest and information, the United States and the European Union could together supply public goods in the global economic order based on Drezner's assessment of the state of play in 2007. ${ }^{132}$ Unity of interest and information, however, may be issuespecific. If so, because each great power must calculate its national interest with regard to each separate issue before deciding whether to cooperate, international regimes organized by k-group coalitions may be more fragmented than those created by hegemons. ${ }^{133}$ Of course, the rise of China as a great economic power and the decline of the European Union in the twenty-first century throws into doubt prevailing assumptions about the sufficiency of the United States and the European Union to constitute a k-group. But it does not contradict the theory of the k-group as a means of providing a public good like an international anticorruption regime. The question is whether China will join the k-group or spoil its effectiveness.

\section{Two-Level Games}

Coordination among states on the international plane, whether through a tightly-focused k-group or a more general and looser multilateral cooperation, depends to a large extent on the scope of possible agreement by any state, which may in turn be constrained by domestic politics. Accordingly, an analytical tool that international relations theorists have used to model the forces at play in international deal-making is the two-level game. ${ }^{134} \mathrm{~A}$ state seeking to negotiate international agreement faces pressures at both the international and domestic

131. Daniel W. Drezner, All Politics is Global: Explaining InTERnational Regulatory Regimes 36 (2007).

132. See generally James D. Morrow, Modeling the Forms of International Cooperation: Distribution Versus Information, 48 INT'L ORG. 387 (1994) (emphasizing problems of information and distribution in the formation of coalitions).

133. Daniel W. Drezner, The Contradictions of Post-Crisis Global Economic Governance, in HANDBOOK of Global Economic Governance: Players, Powers and Paradigms, 345, 353 (Manuela Moschella \& Catherine Weaver eds., 2014) (summarizing literature and noting that increasing the number of relevant actors increases both transaction and bargaining costs as well as the possibility of a wider dispersion of preferences).

134. Robert D. Putnam, Diplomacy and Domestic Politics: The Logic of Two-Level Games, 42 INT'L ORG. 427, 434 (1988). 
levels simultaneously - a two-level game between the state and its domestic interest groups and among other states. ${ }^{135}$

The logic of the two-level game was originally applied to treaty negotiation where the negotiator for a state must deal with international counterparties (Level I) but must also ratify the agreement with his or her domestic constituency (Level II). ${ }^{136}$ This analytic construct enabled theorists to define "win-sets"- that is, a range of outcomes that could be both agreed among the international counterparties at Level I and ratified by the domestic constituency at Level II. ${ }^{137}$ This construct leads to a number of insights, including that the Level I negotiating position is largely determined by what is feasible at Level II. ${ }^{138}$ A negotiator may have more success against his or her international counterparts if he or she can demonstrate very little "deal-space" vis-à-vis the domestic constituency. And developments in domestic politics may expand or restrict the deal space in Level I. By contrast, and perhaps counterintuitively, the greater the ability of a negotiator to win approval at home, the more likely the negotiator can be pushed around by his or her counterparts internationally at Level I. ${ }^{139}$ Moreover, it is theoretically possible that a state (say, the United Kingdom) might be moved by cross-cutting alliances between domestic interest groups (like U.K. businesses with operations in the United States and therefore subject to FCPA compliance) and a foreign state (say, the United States) to acquiesce to an international outcome (say, enforcement of its own foreign anti-corruption laws). Finally, the best sanction for deterring defection might be different in design if aimed at the specific domestic constituency most likely to militate for defection at Level II. ${ }^{140}$

\section{Putting it All Together}

Our account has five parts, with the last two parts incorporating insights borrowed from the international relations theory concerning k-groups and twolevel games. First, as soon as the FCPA was enacted in response to the exogenous shock of Watergate, U.S. companies, realizing that repeal was a political impossibility, urged the U.S. government to push international anti-corruption regulation to level the playing field. ${ }^{141}$ U.S. companies would be at a competitive disadvantage if their foreign rivals could pay bribes to win lucrative procurement, arms, and infrastructure contracts while they could not. If foreign companies, however, could be brought into the anti-bribery fold, then the disadvantage to

135. Two-level games emphasize the role of domestic constituents, even in explaining international outcomes. At the national level, domestic groups pursue their interests by pressuring the government to adopt favorable policies, and politicians seek power by constructing coalitions among those groups. At the international level, national governments seek to maximize their own ability to satisfy domestic pressures, while minimizing the adverse consequences of foreign developments. $I d$.

136. Id. at 436 .

137. Id. at 437 .

138. Id. $442-43,448$.

139. Id. at 440

140. Id. at 460 (noting "the importance of targeting international threats, offers, and side payments with an eye towards their domestic incidence at home and abroad").

141. See supra Section III.C. 
U.S. companies from the FCPA would be neutralized. At the same time, these same business interests lobbied for lax enforcement of the FCPA domestically.

Second, these lobbying efforts bore fruit in the OECD Convention of 1997. The capital-exporting states that signed the Convention passed implementing legislation as per their treaty obligations. At the same time, they did not make serious efforts to enforce these statutes on the books. ${ }^{142}$ In the United States, Congress passed important amendments to the FCPA to implement the Convention including a very broad jurisdictional provision that extended coverage to foreign companies with minimal connections to the United States.

Third, the U.S. government, particularly the DOJ, stepped up FCPA enforcement, especially after $9 / 11$, as part of a renewed focus on the financial aspects of transnational crimes and national security threats. Because of the broad jurisdictional scope of the amended FCPA, some foreign companies doing business in the United States were also swept up into the greater FCPA enforcement dragnet, including U.K., German, French, Israeli, and Brazilian companies. So far, our causal account is principally descriptive and in general agreement with realist, institutionalist, and altruist explanations. The next two Parts are where we deploy international relations theory and diverge from existing accounts.

Fourth, these foreign companies, after being brought within the jurisdictional reach of the FCPA, supported, or acquiesced in, enforcement by their home countries of the foreign anti-corruption laws that had been enacted pursuant to the OECD Convention but left dormant. In other words, a two-level game played out, with the interests of foreign companies subject to FCPA jurisdiction aligned with the United States in ensuring enforcement of foreign anti-corruption laws in their home jurisdictions. This would level the playing field against their domestic and regional competitors who might not be subject to U.S. FCPA enforcement. At the same time, the implicated foreign governments could in theory use the laws to reciprocate against U.S. companies. But generally, U.S. companies were more compliant with foreign anti-bribery laws, having had to live with FCPA compliance for a much longer time.

Fifth and finally, once companies from a k-group of leading countries - for instance, the U.S., the U.K., Germany, France, and Brazil—can plead an inability to give bribes due to a real risk of enforcement of foreign anti-corruption laws in their home jurisdictions when they bid for international contracts in the developing world, the officials in those countries will be left with a difficult choice. Should they award contracts to top U.S., U.K., German, French, or Brazilian companies who cannot offer bribes, or to competitors who can because their home countries do not have foreign anti-bribery laws or only minimally enforce them? In other words, the successful proliferation of a truly global anti-corruption regime depends upon the formation of a k-group of enforcing countries and multinational corporations with sufficient leverage to curtail the giving of bribes on the supply side. It is conceivable that as the k-group grows (e.g., to include other European countries, Japan, or Korea), a tipping point will be reached where

142. See infra Part V. 
potential bribe takers cannot justify taking inferior bids from bribe-paying companies for fear of exposing their bribe taking.

The wild card in our model remains China, which is not currently enforcing foreign anti-corruption laws. Due to its explosive economic growth, China and its companies may command a sufficient share of global capital exports to prevent the formation of a k-group if they continue to pay bribes absent Chinese regulatory enforcement. But enforcing the FCPA against Chinese businesses subject to FCPA jurisdiction while also operating in capital-importing countries may not pressure the Chinese government to enforce its own foreign anti-bribery laws on Chinese companies (although it may enforce them against foreign companies operating in China), since the Chinese government is effectively the entity paying the bribe. Indeed, Chinese foreign policy may be to encourage - not to prohibit-foreign bribes given Xi Jianping's "Belt and Road" Initiative ("BRI"), China's ambitious program of funding and building infrastructure projects in the developing world. ${ }^{143}$ Chinese companies may thus continue to pay bribes to build political capital among developing-world elites. They might even do the work at lower rates thanks to state loans, subsidies, and programs designed to deploy slack capacity from the Chinese construction industry to infrastructure projects abroad. ${ }^{144}$

On the other hand, Chinese companies paying frequent bribes may find themselves blacklisted by the World Bank and other development banks. ${ }^{145}$ Chinese companies might then begin to comply with international norms, and China might enforce its foreign anti-corruption laws to preserve Chinese companies' eligibility for development-bank sponsored projects. Additionally, some developing countries, Malaysia for example, are beginning to push back against BRI, wary of being too much under the influence of China. ${ }^{146}$ And growing economic tensions with the United States may increase U.S. government agency's scrutiny of Chinese companies with U.S. connections, including FCPA enforcement by the DOJ and the SEC. In any event, China is an important case that needs to be examined and analyzed carefully. Part V tests our model with actual case studies.

\section{CASE ANALYSIS OF OUR INTEREST GROUP THEORY}

The OECD Anti-Bribery Convention required ratifying nations to enact domestic foreign-corruption laws similar to the FCPA. Article 2 of the Convention

143. Peter Thomson, President, UN Gen. Assembly, Statement at the Plenary Session of the Belt and Road Forum for International Cooperation (May 14, 2017), https://www.un.org/pga/71/2017/05/14/belt-and-road-forum-for-international-cooperation/.

144. See Spalding, supra note 11, at 394-95.

145. See Combatting Corruption, WORLD BANK (Oct. 4, 2018), http://www.worldbank.org/en/topic/governance/brief/anti-corruption; see, e.g., Press Release, World Bank, World Bank Group Announces Debarment of Two Chinese Construction Companies Working on Energy Product (July 19, 2018), https://www.world bank.org/en/news/press-release/2018/07/19/world-bank-group-announces-debarment-of-two-chinese-construction-companies-working-on-energy-project.

146. Hannah Beech, 'We Cannot Afford This': Malaysia Pushes Back Against China's Vision, N.Y. TIMES (Aug. 20, 2018), https://www.nytimes.com/2018/08/20/world/asia/china-malaysia.html. 
provides that "[e]ach Party shall take such measures as may be necessary, in accordance with its legal principles, to establish the liability of legal persons for the bribery of a foreign public official." ${ }^{147}$ Most of the forty-four OECD signatory countries have in fact passed foreign corruption legislation to comply with the treaty, but enforcement patterns have varied dramatically. According to the 2018 report of Transparency International ("TI"), a non-governmental organization dedicated to monitoring foreign corruption, only seven capital-exporting countries with an aggregate $27 \%$ share of global exports can be characterized as pursuing "active" enforcement: the U.S., Germany, the U.K., Italy, Switzerland, Norway, and Israel. ${ }^{148}$ TI's 2018 report counts four countries (Australia, Sweden, Brazil, and Portugal) with aggregate global exports of 3.8\% as "moderate" enforcers, and eleven countries (including France, Netherlands, and Canada) with aggregate exports of $12.3 \%$ as "limited" foreign-corruption law enforcement countries. ${ }^{149}$ TI reports that twenty-two countries-nearly half of the OECD Convention's signatories (including Japan, South Korea, India, Mexico, and Russia) pursue "little or no" enforcement of foreign corruption laws. ${ }^{150}$

What explains the varying levels of enforcement of foreign corruption laws and how can we predict the future of enforcement patterns? Even among the "active" and "moderate" signatories, enforcement has been a relatively recent trend in the last few years except for the United States, which as described above, dramatically increased FCPA enforcement early in the new millennium.

As set forth in Part IV, our explanatory model focuses on the interests of the U.S. and foreign companies. The basic insight is that as businesses face enforcement of foreign anti-corruption laws in other countries (e.g., the FCPA in the United States), they will push for or acquiesce in enforcement in their own capital-exporting countries to "level the playing field" vis-à-vis competitors who do not face the same enforcement risk. For instance, a German company that is subject to U.S. FCPA enforcement will seek or acquiesce in Germany's enforcement of its own foreign anti-corruption laws. Over time, this will result in more and more capital-exporting countries enforcing their formerly moribund foreign anti-bribery laws that were enacted upon ratification of the OECD Convention. At some point, a k-group on the supply side may trigger a rejection of the bribes that are still being offered on the buy side. This is on the presumption that the bribe-free services or goods provided by the k-group are so objectively superior to what bribers can provide that the potential bribe-taker will have no other option than to take a bid from a k-group provider.

It may help to give concrete examples to understand the model. Recall the extent to which the OECD Convention itself resulted from U.S. businesses lobbying for an international level playing field. Consider, then, the cases of the

147. Org. for Econ. Co-operation and Dev. [OECD], Convention on Combatting Bribery of Foreign Public Officials in International Business Transactions and Related Documents, art. 2 (2011).

148. See Gillian Dell \& Andrew McDevitt, Transparency Int'L, Exporting CorruptionPROGRESS REPORT 2018: AsSESSING ENFORCEMENT OF THE OECD ANTI-BRIBERY CONVENTION 4 (2018).

149. $I d$.

150. $I d$. 
U.K. and Germany - two of the earliest active enforcement jurisdictions. ${ }^{151}$ In fact, the U.K. Bribery Act, which came into force in 2011, is more far-reaching than the FCPA, most prominently in its applicability to foreign commercial bribes paid to private actors, not just foreign officials. ${ }^{152}$ The U.K. Act came into law the year after BAE Systems, a British aerospace and defense company, settled a long-running FCPA investigation that resulted in a \$400 million settlement- the third-largest ever at the time. ${ }^{153}$ Germany has become perhaps the second leading jurisdiction for enforcement of foreign corruption laws in the past few years. From 2007 to 2017, German authorities initiated forty investigations, commenced thirteen actions, and disposed of forty-nine cases with sanctions-a level of enforcement commensurate to U.S. enforcement of the FCPA prior to 2007 in terms of volume, although the targets of investigations were individuals not corporations, and the amounts of sanctions were considerably smaller. ${ }^{154}$ The German technology giant Siemens paid $\$ 800$ million in 2008 to settle an FCPA enforcement action. ${ }^{155}$ That settlement was the largest in the history of foreigncorruption law enforcement until the September 2018 Petrobras settlement was announced.

A pattern emerges, reinforced by the interesting fact that nearly all the "active" or "moderate" enforcement jurisdictions in 2018 are home states of foreign companies subject to FCPA actions by U.S. enforcement authorities that result in very public and large settlements and nonprosecution agreements. For instance, Transparency International's 2018 Report counts Israel as an active enforcer of foreign corruption laws, with thirteen investigations opened between 2014 and 2017 and the country's first ever foreign corruption case reaching settlement in 2016. ${ }^{156}$ Earlier in 2016, Teva Pharmaceuticals Industries-a generic drug maker-paid $\$ 519$ million to settle U.S. FCPA charges that it had paid bribes in Russia, Ukraine, and Mexico. ${ }^{157}$

The causal mechanism is straightforward. When prominent foreign companies like BAE (U.K.), Siemens (Germany), and Teva (Israel) paid fines and made nonprosecution agreements to settle U.S. FCPA prosecutions, they stopped resisting enforcement of analogous laws in their home jurisdictions. Because the expansive jurisdictional reach of the post-OECD Convention FCPA meant that these giant multinational companies could not escape foreign anti-corruption regulation in the United States - a large market they could not forego, their interest in lobbying their home governments for lax enforcement faded. These

151. Id. at 49-51, 88-91.

152. See Bribery Act 2010, § 9, Guidance About Procedures Which Relevant Commercial Organisations Can Put Into Place to Prevent Persons Associated With Them From Bribing, https://www.gov.uk/government/publications/bribery-act-2010-guidance.

153. Richard L. Cassin, BAE Pleads Guilty, FCPA Blog (Mar. 1, 2010, 5:43 PM), http://www.fcpablog.com/blog/2010/3/1/bae-pleads-guilty.html.

154. DELL \& MCDEVITT, supra note 148, at 49.

155. Richard L. Cassin, Siemens to Plead Guilty, FCPA BLOG (Dec. 12, 2008, 6:10 AM), http://www.fcpablog.com/blog/2008/12/12/siemens-to-plead-guilty.html.

156. DELL \& MCDEVITT, supra note 148 , at 56.

157. Press Release, SEC, Teva Pharmaceutical Paying $\$ 519$ Million to Settle FCPA Charges (Dec. 22, 2016), https://www.sec.gov/news/pressrelease/2016-277.html. 
companies would have needed to implement effective FCPA compliance regimes in any event as part of their respective nonprosecution agreements with U.S. authorities. Consequently, companies like BAE, Siemens, and Teva confronted their own level playing field problem vis-à-vis domestic and non-U.S. competitors who were not subject to potential FCPA enforcement because of de minimis operations or contacts within the U.S. And so they acquiesced and even lobbied for more aggressive enforcement in their home countries like the U.K., Germany, and Israel as their level-playing-field antidote. At the same time, the U.S. FCPA prosecutions often required cooperation with home-jurisdiction enforcement authorities which built up capacity and expertise to enforce their own anti-corruption laws. It is telling, for instance, that one recent target of German prosecutors was a subsidiary of Thyssenkrupp Marine Systems - an erstwhile rival (and sometimes ally) of Siemens. ${ }^{158}$ The case was settled by the subsidiary's agreement in 2017 to disgorge 49 million euros - the largest German domestic settlement to date and the first notable one involving a corporate defendant. ${ }^{159}$

The only OECD signatory that was a home jurisdiction for companies subject to high-profile FCPA actions that Transparency International ("TI") did not characterize in its 2018 report as an "active" or "moderate" enforcer is France. ${ }^{160}$ Three French companies were investigated for FCPA violations and agreed to sizable disgorgement settlements: Technip for \$338 million in 2010; Total for $\$ 398$ million in 2013; and Alstom for \$772 million in 2014. ${ }^{161}$ And yet TI concluded that France was a "limited" enforcement jurisdiction. ${ }^{162}$ This finding would appear to contradict our model.

But more recent events on the ground indicate that the model is accurate in its predictions even as to France, but on a longer time horizon. France, despite having ratified the OECD Convention, did not have the legal tools (e.g., an enforcement agency or nonprosecution agreements) to ensure meaningful enforcement of foreign anti-corruption laws. That changed, in large part because of the French government's experience and cooperation with U.S. authorities regarding the three high-profile FCPA actions against French companies mentioned above. In December 2016, France passed the Law on Transparency, Combating Corruption and Modernization of Economic Life, commonly referred to as "Sapin II."163 The law created a new national Anti-Corruption Agency, charged with anti-corruption oversight of big companies including mandated compliance regimes. ${ }^{164}$ The law also instituted much-needed whistleblower protections and excised preexisting rules that the victim or alleged offender be a French citizen and that

158. DELL \& MCDEVITT, supra note 148 , at 49.

159. Id. The relevant German laws were changed in 2015 to allow prosecution of juridical persons like corporations.

160. Id. at 46 .

161. Richard L. Cassin, With Alstom, Three French Companies Are Now in the FCPA Top Ten, FCPA BLOG (Dec. 23, 2014, 9:45 AM), http://www.fcpablog.com/blog/2014/12/23/with-alstom-three-french-companies-arenow-in-the-fcpa-top-t.html\#sthash.fFBa7gKy.dpuf.

162. DELL \& MCDEVITT, supra at 148 , at 2.

163. Id. at 47.

164. Id. 
the conduct at issue must be an offense in both France and the territory in which it took place. ${ }^{165}$ Perhaps most importantly, Sapin II introduced a new tool analogous to the U.S. deferred prosecution agreement - the convention judiciaire d'intérêt public ("CJIP"). ${ }^{166}$ The first CJIP was made with Hong Kong Shanghai Banking Corporation ("HSBC") Private Bank Suisse (a Swiss subsidiary of the storied Hong Kong banking institution), involving secret bank accounts of French taxpayers. ${ }^{167}$ In November 2017, the Paris High Court approved the CJIP to settle the matter without admitting guilt subject to a 300 million euro settlement including disgorgement and fines. ${ }^{168}$

Like France, it is possible to make a prediction on the future course of the enforcement of foreign anti-corruption laws in Brazil based on our model. In light of the historic Petrobras settlement - the first to pass the $\$ 1$ billion mark in terms of total value ${ }^{169}$ - one would expect Brazil to ramp up enforcement of its own foreign anti-corruption laws, particularly against foreign companies. Because Petrobras was a state entity, the Brazilian authorities cooperated very closely with the United States SEC and DOJ in the matter, and a significant portion of the recovery will go to Brazil. ${ }^{170}$ Like their French counterparts, the Brazilian enforcement agencies likely learned a great deal from their cooperation with the U.S. authorities. At present, TI reports that Brazil is a "moderate" enforcer. ${ }^{171}$ If we are right, that characterization will change in the future, although Brazil, like France, may need some time to develop the necessary legal architecture, including the development of a specialized enforcement agency, enhanced whistleblower protections, and the implementation of nonprosecution agreements.

According to TI, the three largest economies with "little or no" enforcement of foreign corruption laws between 2014 and 2017 are China (10.8\% of global exports), Japan (3.8\%), and South Korea (3.0\%). ${ }^{172}$ China is not a signatory of the OECD Convention (although it has ratified the UNCAC), and, as noted above and discussed below, is a special case given the role of the state in the economy. Consequently, our model, which is premised on the influence of business interests as independent actors, cannot explain China well. Japan and South Korea are different: they are signatories to the OECD convention, and big business groups have been dominant players in both capital-exporting Asian economies. What explains the recent lack of enforcement in those countries?

165. Id.

166. Id.

167. Id.

168. Id.

169. Press Release, DOJ, Petroleo Brasileiro S.A.-Petrobras (Sept. 26, 2018), https://www.justice.gov/ opa/press-release/file/1096706/download; Petróleo S.A.-Petrobras, Securities Act Release No. 10561, Exchange Act Release No. 84295, 2018 WL 4628173 (Sept. 27, 2018).

170. Richard L. Cassin, Petrobras Reaches \$1.78 Billion FCPA Resolution, FCPA BLOG (Sept. 27, 2018, 9:28 AM), http://www.fcpablog.com/blog/2018/9/27/petrobras-reaches-178-billion-fcpa-resolution.html.

171. DELL \& MCDEVITT, supra note 148 , at 4.

172. Id. at 10 . 
Japan is a particularly interesting case because there have in fact been several FCPA settlements involving Japanese companies. In April 2018, Panasonic Corporation agreed to pay $\$ 143$ million in disgorgement of profits and prejudgment interest to settle FCPA claims related to bidding for in-flight entertainment and communications systems. ${ }^{173}$ Its U.S. subsidiary, Panasonic Avionics Corporation, agreed to a criminal fine of more than $\$ 137$ million as part of a deferred nonprosecution agreement in conjunction with the same crime. ${ }^{174}$ In 2011, JGC Corporation, a Japanese energy, procurement, and construction ("EPC") company paid \$219 million to settle FCPA charges for conspiring with the U.S. company KBR/Halliburton to pay bribes to Nigerian officials on the Bonny Island Liquid Natural Gas project. ${ }^{175} \mathrm{KBR} /$ Halliburton, the principal conspirator, itself paid a $\$ 579$ million settlement in 2009, the largest FCPA settlement paid by an American corporation. ${ }^{176}$ The Japanese trading company Marubeni paid \$54.6 million in connection with the Bonny Island project in 2012. ${ }^{177}$ Marubeni also pled guilty in 2014 to FCPA violations for payments made relating to the Tarahan power project in Indonesia and paid $\$ 88$ million. ${ }^{178}$ Olympus of America, a wholly owned subsidiary of Olympus Corporation of Japan, also paid a \$22.8 million in FCPA fines as part of a deferred prosecution agreement in 2016 with respect to bribes paid for medical equipment contracts in Latin America. ${ }^{179} \mathrm{Hi}-$ tachi reached a settlement with the SEC in 2015 to pay $\$ 19$ million to settle bribery charges with respect to power station orders in South Africa. ${ }^{180}$

Why have Japanese business interests not mobilized to encourage the Japanese government to "level the playing field" and ramp up enforcement of its own foreign anti-corruption laws given this track record of FCPA enforcement against Japanese multinational companies? Several factors may be at work. First, it may be that the scale of the penalties, while large, has not reached headlines level, i.e., \$500 million or \$1 billon. And the optics and demonstration effect of

173. Press Release, SEC, Panasonic Charged With FCPA and Accounting Fraud Violations (Apr. 30, 2018), https://www.sec.gov/news/press-release/2018-73.

174. Id.

175. Richard L. Cassin, JGC Resolves Criminal Charges, FCPA BLoG (Apr. 6, 2011, 3:18 PM), http:// www.fcpablog.com/blog/2011/4/6/jgc-resolves-criminal-charges.html.

176. Id.

177. Press Release, DOJ, Marubeni Corporation Resolves Foreign Corrupt Practices Act Investigation and Agrees to Pay a \$54.6 Million Criminal Penalty (Jan. 17, 2012), https://www.justice.gov/opa/pr/marubeni-corporation-resolves-foreign-corrupt-practices-act-investigation-and-agrees-pay-546.

178. Press Release, DOJ, Marubeni Corporation Agrees to Plead Guilty to Foreign Bribery Charges and to Pay an \$88 Million Fine (Mar. 19, 2014), https://www.justice.gov/opa/pr/marubeni-corporation-agrees-pleadguilty-foreign-bribery-charges-and-pay-88-million-fine.

179. Deferred Prosecution Agreement at 7, United States v. Olympus Latin America, Inc., No. 16-CR-3525 (D.N.J. Mar. 1, 2016).

180. Case Information: Securities and Exchange Commission v. Hitachi, Ltd., STANFORD LAW SCH.: Foreign CORRUPT PRACTICES ACt Clearinghouse, http://fcpa.stanford.edu/enforcement-action.html?id=576 (last visited July 22, 2019). The Japanese company Bridgestone also agreed to pay a fine of \$28 million to settlement charges of Sherman Antitrust Act and FCPA violations concerning marine-hose orders. The maximum amount chargeable for the FCPA violation, however, was $\$ 500,000$, so the overwhelming part of the settlement was for the antitrust violations. Press Release, DOJ, Bridgestone Corporation Agrees to Plead Guilty to Participating in Conspiracies to Rig Bids and Bribe Foreign Government Officials (Sept. 15, 2011), https://www.justice.gov/opa/pr/bridgestone-corporation-agrees-plead-guilty-participating-conspiracies-rig-bids-and-bribe. 
the largest settlement-the $\$ 219$ million paid by JGC in 2011 - was watered down by the fact that Japanese companies were junior partners in the Bonny Island project syndicate. The leader was a U.S. company, KBR/Halliburton, which had paid \$579 million two years earlier. ${ }^{181}$ Second, Japan may lack the legal infrastructure to enforce foreign anti-bribery laws effectively against corporations. Like France before it enacted Sapin II, Japan did not have a mechanism to allow deferred prosecution agreements until an amendment to their criminal procedural code came into effect on June 1, 2018. ${ }^{182}$ Moreover, Japanese law does not afford strong protection for whistleblowers, a critical catalyst to foreign anti-bribery prosecutions. Finally, implementation of the OECD Anti-Bribery Convention in Japan largely falls under the remit of the Ministry of Economy, Trade, and Industry, which is also responsible for the promotion of Japanese businesses abroad, a dual mandate which creates obvious tensions. ${ }^{183}$

By contrast to Japanese companies, no South Korean company has entered into a deferred prosecution agreement with U.S. authorities and paid sizable fines regarding FCPA violations. That may change in the future, but it seems that a high-profile, big-number FCPA settlement may be a necessary catalyst to the change. Additionally, South Korea lacks some of the same safeguards and cultural norms regarding whistleblowers as Japan. But we believe that our model will eventually apply to Japan and South Korea, given the strength of business interests in both countries and their liberal democratic political orders. As such, we predict that:

(1) there will be a large-scale U.S. FCPA (or other k-group) investigation and settlement involving flagship multinational companies in the two countries (in the hundreds of millions of dollars range);

(2) the respective national enforcement authorities will be involved;

(3) Japan and South Korea will subsequently enforce their national foreign anti-bribery laws, with the acquiescence or encouragement of the multinational companies already subject to enforcement in k-group jurisdictions; and

(4) eventually, Japan and South Korea will join the k-group, increasing the momentum toward a truly global anti-corruption regime.

China is the country with the largest share of global exports- $10.8 \%$, by comparison to the U.S. share of $9.9 \% .{ }^{184}$ Although it is not a signatory of the OECD anti-bribery convention, it acceded to the U.N. Convention Against Corruption ("UNCAC") in 2006. ${ }^{185}$ In 2011, China amended its criminal code to criminalize the bribery of foreign officials:

181. Cassin, JGC Resolves Criminal Charges, supra note 175.

182. DELL \& MCDEVITT, supra 148 , at 60.

183. Id.

184. Id. at 10 .

185. Signature and Ratification Status, United NATIONS Off. ON DRUGS \& CRime, https://www. unodc.org/unodc/en/corruption/ratification-status.html (last visited July 14, 2019). 
Whoever gives any property to a staff member of a company, an enterprise or any other entity for any improper benefit shall be sentenced to imprisonment of not more than 3 years or criminal detention if the amount of property is relatively large; or be sentenced to imprisonment of not less than 3 years but not more than 10 years and a fine if the amount of property is huge. Whoever gives any property to a functionary of a foreign country or an official of an international public organization for any improper commercial benefit shall be punished according to the provision of the preceding paragraph. Where an entity commits a crime as provided for in the preceding two paragraphs, a fine shall be imposed on it, and its directly responsible person and other directly liable persons shall be punished according to the provision of paragraph 1 of this Article. A briber who voluntarily confesses to his bribery before a criminal investigation on him is opened may be given a mitigated penalty or be exempted from penalty. ${ }^{186}$

Although this amendment - known as the Foreign Bribery Provision — satisfied UNCAC's requirement to enact domestic foreign anti-bribery laws, UNCAC does not require enforcement. ${ }^{187}$ UNCAC does allow and encourage signatories to engage in peer or expert review of their respective anti-corruption initiatives and programs, and China has "firmly opposed review mechanisms that go beyond self-assessment." ${ }^{188}$ Commentators and observers have generally concluded that the enactment of the new Chinese foreign-bribery law was a symbolic gesture, with little or no possibility for enforcement. ${ }^{189}$ Indeed, the OECD has criticized the enacted law as "being deliberately designed to avoid strict enforcement. The absence of any meaningful sanctions against Chinese companies for offences abroad to date corroborates this criticism. Overall, China's approach has been one of attentively observing and selectively transposing transnational anti-bribery standards without showing any signs of enforcement." 190 Additionally, one U.S. commentator has asserted that the Chinese law relating to bribery of foreign officials requires intent that appears to be facially more limited than the requisite intent for domestic bribery: "It therefore appears that giving a bribe to a foreign public official to secure non-commercial benefits, which would be prohibited in the domestic context, may be permissible in a foreign context." 191 To date, China has not brought any reported charges against Chinese nationals or corporations for paying foreign bribes.

186. Eight Amendment (中文版) [Criminal Law] (promulgated by the Standing Comm. Nat'l People's Cong., Feb. 25, 2011, effective May 1, 2011), art. 164, 2011, https://www.cecc.gov/resources/legal-provisions/eighth-amendment-to-the-criminal-law-of-the-peoples-republic-of-china.

187. Jeffrey Young, Corruption Concerns Taint Burgeoning China-Africa Trade, VOA (Sept. 1, 2014, 7:00 AM), https://www.voanews.com/a/corruption-concerns-tain-buregeoning-china-africa-trade/2432469.html; see also Samuel R. Gintel, Fighting Transnational Bribery: China's Gradual Approach, 31 WIS. INT'L L.J. 1, 26 (2013).

188. Gintel, supra note 187 , at 26.

189. Id. at 9.

190. Bertram Lang, Engaging China in the Fight Against Transnational Bribery: "Operation Skynet" as a New Opportunity for OECD, OECD GLOBAL ANTI-CORRUPTION \& InTEGrity Forum 8 (2017), https://www.oecd.org/cleangovbiz/Integrity-Forum-2017-Lang-China-transnational-bribery.pdf.

191. Gintel, supra note 187 , at 19. 
There is some reason for hope. Since taking power, President Xi Jianping has made the fight against domestic corruption a high priority. ${ }^{192}$ Thus, he created a powerful new anti-corruption agency, the National Supervision Council, with the mission of overseeing "all public servants exercising public power." 193 As with Watergate in the United States, illegal funds used domestically may lead to the discovery of such funds used abroad. And the payment of bribes by Chinese companies has led to many of them being blacklisted from participating in infrastructure projects sponsored by the World Bank and regional development banks like the Asia Development Bank. ${ }^{194}$ There were reports in October 2015, for instance, that Chinese officials were investigating individuals possibly connected with corruption related to Sinopec's oil exploration in Angola. ${ }^{195}$ At the same time, the Chinese government has done nothing to address western news reports of rampant payment of bribes on behalf of Chinese business in Africa, for example, by Hong Kong businessman Chi Ping Patrick Ho. ${ }^{196}$

At the end of the day, it is not clear that Chinese multinational companies subject to FCPA or other anti-corruption law enforcement abroad can mobilize the Chinese government to enforce its own foreign anti-bribery laws against all Chinese companies to level the playing field. Most daunting is the fact that the present Chinese government perceives an affirmative strategic interest in paying bribes to secure infrastructure contracts in the developing world and developing economic and political bonds. That is the point of the so-called "Belt and Roads" initiative. And given the large share of world exports originated by Chinese companies, China's intransigence may be enough to stymie the k-group.

In December 2018, the DOJ and the SEC announced an FCPA settlement with Polycom, a U.S. telecommunications technology company, based on bribes paid to Chinese officials by its Chinese subsidiary. Polycom agreed to pay the SEC \$16.3 million (\$10.7 million to disgorge illicit profits, $\$ 1.8$ million for prejudgment interest, and \$3.8 million fine) $)^{197}$ and an additional \$20.3 million to the U.S. Treasury and Postal Service Consumer Fraud Fund pursuant to a DOJ nonprosecution letter agreement. ${ }^{198} \mathrm{~A} \$ 36.6$ million dollar settlement is not large by the standards of recent FCPA settlements, and the company in question was a U.S. corporation that had recently acquired the Chinese company which had

192. China is Conducting Fewer Local Policy Experiments Under Xi Jinping, ECONOMIST (Aug. 18, 2018), https://www.economist.com/leaders/2018/08/18/china-is-conducting-fewer-local-policy-experiments-under-xijinping.

193. Pratik Jakhar, China's Anti-Corruption Campaign Expands With New Agency, BBC (Mar. 20, 2018), https://www.bbc.com/news/world-asia-china-43453769.

194. Anticorruption and Integrity: Sanctions, ASIAN DEV. BANK, https://www.adb.org/site/integrity/sanctions (last visited July 14, 2019).

195. Sun Hong \& SAKi Chen, Bribery and Corruption OfFences, Enforcement and Penalties: ChINA 10, Westlaw Practical Law UK Practice Note (updated Jan. 2019).

196. Jenni Marsh, How a Hong Kong Millionaire's Bribery Case Exposes China's Corruption Problem in Africa, CNN (Feb. 10, 2018), https://edition.cnn.com/2018/02/09/world/patrick-ho-corruption-china-africa/index.html.

197. Polycom, Inc., Exchange Act Release No. 84978, 2018 WL 6804090 (Dec. 26, 2018).

198. Polycom, Inc., SEC No-Action Letter (Dec. 20, 2018), https://www.justice.gov/criminal-fraud/ file/1122966/download. 
paid the bribes to Chinese officials before its acquisition. But it may signal a start to more robust FCPA enforcement against Chinese companies, particularly in the context of the current trade war between the United States and China. And if so, it may be an early sign that the model we have set forth may yet have explanatory purchase to Chinese business interests.

\section{CONCLUSION}

In this Article, we have sought to make four contributions to the literature. First, this Article is the first to examine global enactment and enforcement patterns of foreign corruption laws in a theoretically informed way. Prior accounts have focused primarily on explaining the enactment of the FCPA and its enforcement trends and have devoted much less effort to explaining other states' foreign corruption laws. Others have told a story about the U.S. government's interests or rent-seeking by prosecutors to explain the international spread of such laws. By contrast, this Article has focused on the organic growth of such laws, spurred by the interests of each state's domestic business lobby. Under the right circumstances, we have shown that these incentives could create a domino effect in the enforcement of national foreign anti-corruption laws that would explain the actual patterns we observe in the world.

Second, our account has illuminated a critical distinction between foreign anti-corruption laws and anti-corruption laws more generally. This analytical isolation has emphasized just how unusual outbound foreign anti-corruption laws are as well as how they differ in form and function from strictly domestic anticorruption laws.

Third, our account generates predictions and a normative vision for the future. On the assumption that eradicating corruption is a public good, our story shows that it does not necessarily follow that achieving the goal requires topdown norm enforcement along the lines of the traditional international governance model. It is possible, rather, that the same result might be achieved among decentralized sovereign states by the independent actions of leading states brought about by business interests seeking to maximize their own profits. Such a market-based model may have applications in other international contexts where the conventional wisdom emphasizes international laws and institutions as the principal causal mechanism.

Finally, from a methodological perspective, the Article highlights the value of interdisciplinary approaches that combine legal analysis with international relations theory. In particular, hegemonic stability theory, which had its heyday in international relations scholarship pertaining to international political economy and free trade in the 1980s and 1990s, has never been applied to anti-corruption scholarship despite its obvious fit and explanatory leverage to the issue. We do not claim that our theory of the transmission of foreign anti-bribery laws explains every case. In some cases, there may indeed be rent-seeking prosecutors or altruistic policymakers. Still, we think it is an important contribution with real explanatory traction and predictive power. We hope that it will inform the debate of how best to spread anti-corruption norms worldwide. 